NASA Technical Memorandum 102680

\title{
Free Vibrations of Thin-Walled Semicircular Graphite-Epoxy Composite Frames
}

Huey D. Carden, Ahmed K. Noor, and Jeanne M. Peters

May 1990

(NASA-TM-10?GAO) TREF VIBRATIUNS G 



\title{
FREE VIBRATIONS OF THIN-WAILED SEMICIRCULAR GRAPIITE-EPOXY COMPOSIITE FRAMES
}

\author{
Huey D. Carden* \\ NASA Lingley Research Center \\ Hampton, VA \\ Ahmed K. Noor** and leanne M. Peters $\dagger$ \\ Cieorge Washington University \\ NASA Lingley Research Cener \\ Hampion. VA
}

\begin{abstract}
$A$ detailed study is made of the effects of variations in lamination and malerial parameters of thin-walled composite fiames on their vibrational characteristics. The structures considered are semicircular thin-walled frames wilh I and J sections. The flanges and wehs of the frames are moxleled by using two-dimensional shell and plate finite elements. A mixed fommulation is used with the fundamental unknowns consisting of moth the generalized displacements and stress resultants in the frame. The frequencies and moxles predicted by the twodimensional finite element moxlel are compared with those ohtinined from experiments, as well as with the predictions of a one-dimensional thin-walled heam finite element molel. $A$ detailed study is made of the sensitivity of the vibrational response lo varianions in the fiber orientation, material properlies of the individual layers, and boundary conditions.
\end{abstract}

\section{Introduction}

The physical understimbling and the numerical simulation of the dynimic resmmse of laminated anisomropic structures have recently become the focus of intense efforis lecaluse of the expanded use of fibrous composites in aerospice, antomolive, shiphuilding, and other industries, and the need to estahlish the practical limits of the dynamic load-carrying capability of structures made from these materials. Reforences $1-4.5$ are indicalive of the general interest and elforts focused on various aspects of the vibration of structures. Experimental studies have leen performed on the free vibration and impact-response "f thin-walled composite frames and stiffeners. ${ }^{14}$ Onedimensiomal theories have heen developed for the stalic, vilualion and huckling analyses of thin-walled frame struclures. ${ }^{\text {* }}$ Ilowever. no systemitic assessment has heen minle of the range of validity of the basic assumptions of these lheories. Approximate analytical and mumerical technicjues have heell applied to the study of the vibrational response of isotropic and composite stiffeners." 21 Only at few publicantoms ${ }^{22.23}$ examine the effects of variations in lamination

\footnotetext{
*Assistamı Tead. Landing and Impact Dymanics Branch

**Professor of Fingineering and Applied Science

tProgrammer Analyst
}

and geometric paranneters of compmsite paneis on their vilorational characteristics, and these publications do not consider thin-walled composite frames.

The present study summarizes the results of a recent study (Noxr. Carden. Peters) ${ }^{24}$ on the effects of varialions in the lamination and geometric parameters of thin-walled connmosite frames on their vibrational characteristics ffrepuencies, and energy components associated with different modes). The frames consiclered are semicircular, made of thin-walled graphile-epoxy material with I and $J$ sections and have a 36-inch radius (see Fig. 1).

\section{Analysis}

\section{Computational Moxdels}

Two computational moxlels are used for the thin-walled composite frames study. In the first model, the flanges and web are moleled using two-dimensional shell and plate finite elements. The second model is a finite element discretizition of the one-dimensional Vlasov's type thin-walled beam theory. Henceforth, the two moxlels will be referred (o) as Iwodimensional (2D) and one-dimensional (ID) finite element moxdels, respectively.

\section{Mathematical Formulation}

a) Two-dimensional moxlels. The analytical fommulation for the two-dimensiomal mkxlels is based on the SamdersBudiansky shell theory with the effects of transverse sheal defommation. and laminated anisotropic material respmuse included. A mixed fommulation is used with the fundimential unknowns consisting of both the generalized displacements and the stress resultants in the frame (see Fig. 2 for the sign convention).

Bicubic shape functions are used to approximate each of the generalized displacements and the stress resultants. The number of displacement nodes in each element is 16. The siress resultants are allowed to be discontinuous at interelement boundaries. The total number of stress-resultant parameters in each element is 128 . The elenemt clatracteristic arrays are obtained by using the Iwo-field Hellinger-Reissner mixed variational principle. 
b) One-dimensionat mixdels. The analytical formulation for one-dimensional muxtels is hased on a form of Vlasov's linil-willed heam theory with the effects of flexural-torsional conpling. Iramsverse shear deformation, and rotary inertia included. The fundimental unknowns consist of seven infernal forces and seven generalized displacements of the beam (see lig. 3 for the sign convention). The element characteristic arrays are obtained by using a modified form of the HellingerReissner mixed variational principle. The modification consists of angmenting the functional of that principle by two terms: 1) the Lagrange multiplier associated with the conlstraint condition relating the rotation of the cross section and the iwist degrees of freedom: and 2) a regularization term that is cundratic in the Lagrange multiplier. Only $\mathrm{C}^{\text {" }}$ continuity is reyuired for the generalized displacements. Lagrangian interpolation functions are used for approximating each of the generalizeal displacenents, intermal forces and Iagrange multiplier. The polymomial functions for the internal forces and the Lagrange multiplier are one degree lower than those of line generalized displacements. In the present study cuadratic polymomials are used in approximating the generalized displacements. Linear polynomials are used in approximating cach of the intermal forces and the Lagrange mulliplier. The internal forces and the Lagrange multiplier are allowed in be discomtinuous al interelement txundaries. For each element the motal number of generalized displacement parameters is 21 , the lotal number of internal force parameters is 14 and the lonal numlret of I alguange muluiplier parameters is 2. Newr, Peters and Min ${ }^{29}$ present the fundamemal equations of the thin- walled Iteillin theory.

For unusi-isotropic lanminated composites, numerical experimems to be described subsepuently have demonstralted thal reasomably accurate results can be obtained using the one-dimensional molel when the laminated composite is replaced hy an expuivaten isotropic material with the following Young's and shear mexluli:

$$
\begin{aligned}
& I:=\Lambda_{11} / h \\
& G=\Lambda_{1} / h
\end{aligned}
$$

where $\Lambda_{11}$ and $\Lambda_{11}$ are the extensional stiffness in the $x$ direclinn. and the in-plane shear stiffiness used in the classical lamination theory, respectively: and $h$ is the total wall thickness (oi the flange or weh). This approximallion was aldepled in the prexent slukly.

\section{Dinite I:lenkm Eyuations}

The finite element equations for ench individual element al the 11 ) and 21 ) mulels can be cast in the following compact form:

$$
\left(|\stackrel{+}{\mathrm{k}}|-\left(0^{2}|\stackrel{*}{\mathrm{M}}|\right)|Z|=0\right.
$$

where $\{Z\}$ is the vector of the element degrees of freedom: (1) is lie frequency of vihration: $|\stackrel{*}{K}|$ and $\left|M^{*}\right|$ are the generalized stifluess and mass matrices. The explicis forms of matrix arrays associalteal with $|7|,,|\stackrel{+}{\mathrm{K}}|$ and $|\stackrel{*}{\mathrm{M}}|$ are given in Noor and
Anderson ${ }^{2 h}$, and Noor and Peters ${ }^{27}$ for the two-dimensional models, and Noor, et al ${ }^{25}$ for the one-dimensional moxtel.

Vibrational Sensitivity 10 Variations in Lamination and Mate. rial Parameters

The expressions for the sensitivity derivalives of the frequency and response vector with respect in the lamination and material parameters. $\lambda_{i}$, of the composite frames are given hy: $:^{28}$

$$
\frac{\partial v^{2}}{\partial \lambda_{i}^{-}}=\sum_{\text {acuments }}\{Z\}^{\prime}\left(\frac{\left.\partial\right|_{k} ^{*} \mid}{\partial \lambda_{i}^{\prime}}-(1)^{2} \frac{\partial|\stackrel{*}{M}|}{\partial \lambda_{i}^{\prime}}\right)|Z|
$$

and

$$
\frac{\partial\left\{Z_{i}\right\}}{\partial \lambda_{i}}=|Z|+c_{i}\{7\}
$$

where $\{\stackrel{*}{Z}\}$ represents a particular solution of the ecpuations:

$$
\left(|\stackrel{*}{K}|-()^{2}|\stackrel{*}{M}|\right) \frac{\partial\{Z\}}{\partial \lambda_{i}}=-\left(\frac{\partial|\stackrel{*}{k}|}{\partial \lambda_{i}}-(1)^{2} \frac{\partial|\stackrel{*}{M}|}{\partial \lambda_{i}}-\frac{\partial()^{2}}{\partial \lambda_{i}}|\stackrel{*}{M}|\right)|7 .|
$$

and $c_{i}$ are mulipliers given by:

$$
c_{i}=-\sum_{\text {clemente }}\left(\left\{Z^{*}\right\}^{\prime}|M| \mid Z\right\}+\{Z\}^{\dagger}\left[\frac{\partial M}{\partial \lambda_{i}}\right]\{Z \mid)
$$

In Eys. 4 to 7 , the eigenvectors are assumed in be mor malized with respect to $\left|M^{*}\right|$. i.e.

$$
\mid Z\}^{\prime}|\stackrel{+}{M}|\{Z\}=1
$$

The expressions for the total complementary strain energy of the frame. $U^{r}$. and its derivatives with respect of $\lambda_{i}$. are given hy:

$$
W^{c}=\frac{1}{2} \sum_{\text {(lintunts }}\{H\}^{\prime}|F|\{H\}
$$

and

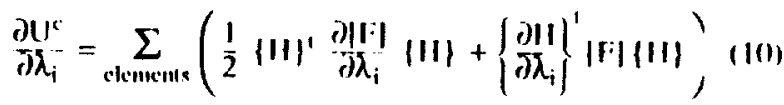

For the purpose of oldaining amalytic derivatives with tespect (o) some of the lamination parameters, such as the filker oriemation angle of different layers. it is convenient to express $\frac{0 y_{1}}{\partial \lambda_{i}}$ in terms of $\frac{\partial|r i|}{\partial \lambda_{i}}$ as follows:

$$
\frac{\partial|\Gamma|}{\partial \lambda_{i}}=-|\Gamma| \frac{\partial|F|^{-1}}{\partial \lambda_{i}}|F|
$$

The matrix $\frac{\partial|\Gamma|^{-1}}{\partial \lambda_{i}}$ is evaluated using the matlytical derivatives of the material stiffness matrix of each laminate fflanges and 
web). The matcrial stiffness matrix of the laminate is given in Jones."

\section{Experimental and Numerical Studies}

\section{Apparatus and Tesı Procedure}

a. Specimons. Two specimens, shown in Fig. 4, were lested. an I-section and a J-section frane. Nominal dimensions of each cross section are shown in Fig. I. Weight of the frame sections was 3.181 and $4.085 \mathrm{lb} .(1.443$ and $1.8 .53 \mathrm{~kg})$ for the 1 and J frames, respectively. The frame sections were made from AS.4/5208 graplite/epoxy unidirectional tape layed up in a manner which resulted in essentially uniform stiffness properties in the circumferential direction (i.e., the stiffness coeffi(icnts are imbependent of $\bar{\theta}$ ). The material properties for the individual layers are given in Fig. 1 . The laminate stacking secjuence for the I-section was $| \pm 4.5 /() / 9()|_{\text {, and }}| \pm 45 /() / 9()|_{2}$, for the I-section. Ench frame section was semicircular with a dianceler of 72 inches $(1.8288 \mathrm{~m}$.). Bonded to the outside flamge of each frame was a sixteen-ply $\left( \pm 45 /(1 / 9())_{2 s}\right.$, quasiisolropic skin made of the same malerial. The frane sections were constructed so that the skin would extend 0.5 inches (0.0127 m.) heyond each side of the bottom flange of the frame. Measured dimensions were used in one of the finiteclement moxlels and results were compared to nominal dinension results and the experimental data.

b. Instrumentation and test method. $A$ photograph of the lest ecjuipment and composite frame specimens is shown in lig. 4. The ends of the frame sections were ponted in a fixture which was bolled to a large steel leam backstop.

An air-shaker, commecled lo an air compressor. was used M excite all test specimens. Excitation was hulh in-plane (radially). and out-of-plane. For in-plane excitalion, the shaker was positioned so that the pulses of air struck approximalely along a normal (o) the surface of the skin. For out-of-plane excilation, a piece of styrofoam was attached to the side of the frame hy double-sided adhesive tape. Pulses of air struck the flat face of the styrofoam along a normal to the face. The position of the air-shaker was aljusted if the excitation was striking on a nole.

^ miniature accelerometer was antached at a fixed lixilion to the frame sections with double-sided adhesive lape. Dunput from the accelerometer was amplified and displayed along the vertical axis of an oscilloscope. Natural modes were deternined hy tuning the excitation frequency of the air-shaker In profluce an acceleration maximum on the vertical deflection mi the ascilloscope. Output also pissed through a low pass filter and was displayed as vibrational freepuency on a frefuxency counter.

$\Lambda$ handlield veloxity prohe was moved along the frame to determine noxle lecitions and moxle shipes. The output of the protere was displayed along the horizontal axis of the oscilloscope. The prohe and accelerometer cuuputs combined to creitte a I.issajous pattern on the oscilloscone. A phase shift in the Lissigous pattern occurred when the velocity probe passed aver a noxle.
Since manual equipment was used in mapping the nodal Iocitions during the vibration survey of the frames, only nodal lines ussoxiated with gross in-plane, and gross out-of-plane motions were monitored. Other nodal lines. associaled with Incalized deformation palterns were not surveyed. These localized deformations were noticeable in some of the higher vibration nodes, with complex deformation patterns and/or strong coupling between in-plane and out-of-plane molions.

\section{Finite-Element Grids}

Two-dimensional models were generated for the actual frames (test specinens) described in the preceding subsection. as well as for the corresponding frames with mominal dimensions. Henceforth. the frames with actual and nominal dimensions will be referred to as the aclual and nominal frames. respectively. For the actual frames. spline interpolintions through measured dimensions were used to generate the wall thicknesses and coordinates of the nodal points. Isoparnmetric finite elenients were used 10 approxinate the variations in stiflnesses and geometry. The one-dimensional models considered herein are for the frames with nominal dimensions. The gricls used for both the one-dimensional and two-dimensional models are described subsequently.

Turo-dimensional models. An $18 \times 8$ grid was used for modeling the whole I-section frame. In this grid two elenents were used to model ench of the weh, top and bottom flange sections. The part of the skin adjacent to the bottom flange section was treated as part of the flange. One element was used to moxtel each of the two parts of the skin section extending beyond the touttum flange (see Fig. 1). The midalle surfaces of the iop flange and the web were taken to he their reference surfaces. The middle surface of the combined bottom flange and skin was taken lo be the reference surface.

An $18 \times 7$ grid was used for moxleling the whole J-section frane. The distribution of the elenrents was similar to the I-section frame. Only one element was used to noxlel the lop flange section (see Fig. 1).

Tolally clamped and partially clamped support conditions nere considered. For totally clamped supports, all the six generalized displacements were restrained

$\left(u_{1}^{\prime}=u_{2^{\prime}}=w^{\prime}=\phi_{1}=\phi_{2^{\prime}}=\phi_{3^{\prime}}=()\right)$. The parrially clamped

conditions were obtained from the totally clamped case by successively removing the restraints on one. as well is on combinations, of the displacement and rotation components.

One-dimensional models. A uniform grid of 24 elements was used in moleling each of the I-section and J-section frames. The principal sectorial properties of the cross section were evalunted using the Fortran program listed in Coyette.

Identification of Modes and Estimation of the Error in the One-Dimensional Model Prediclions

The iwo-dimensional molels cin be used to: al idlentify the in-plane, out-of-plane and conpled moxtes, and h) extimale the error in the predictions of the one-dimensional moxlets. This is accomplished through decomposing the complementiny 
strain energy. (l', Fas. 9. associatled with each vihnation mole. inlo three components, $U_{1}, U_{2}$ and $U_{1}$ (see Table 1 ). The first iwo components, $U_{1}$ and $U_{2}$ are associated with the in-plane and unt-of-plane stress resultants, respectively. The third component. $\mathrm{U}_{3}$, is associated witl the stress resultants which are particular to two-dimensional plates and shells (not present in one-dimensional heam moxtels). The in-plane and out-ofplane moxles correspond to the moxes for which $\mathrm{U}_{1} / \mathrm{U}^{\mathrm{c}}$ and $\mathrm{I}_{2} / \mathrm{Cl}^{\prime}$ are close $\mathrm{IO}$ I. respectively. The stromgly coupled moxtes correspromd to nearly equal values of $U_{1} / U^{r}$ and $U_{2} / U^{*}$. The ralion $U, / U^{\circ}$ is indicative of the error in the one-dimensional munlel predicions.

It is also useful to partition the otal complententary stain energy. associated will each moxde, into thee commonents, $U_{1 f}, U_{w}, U_{\text {h }}$ representing the countributions of the top Ilange, weh, and bottom Hange (including the skin).

\section{(imparison of Experimental and Finile-Element Results}

The resulis of the experimental and numerical studies are summarized in Figs. 5 through 9 and Tible 2 for the I-section fiame. and in Figs. IO through 14 and Table 3 for the J-section frame. For the finite element monlel three cases are considered. namely. Wolally clamped edges (with both anuslational and mattional restraimss, partially clamped edges with $\phi_{2}$, not resirained, and partially clamped edges (with $u_{1}$ - in the flanges ind $\phi_{2} \cdot$ not res(rained).

The maximum and minimum values of the frequencies ohinined by the two-dimensional finite element model comespending or the totally clamped and partially clamped erlges) are shown in ligs. 5(it) and $10($ al) along with lhe exporimental freguencies. (See also Tables 2 and 3). Note that the experimental frepuencies associated with moxle 9 of the I section, and of the J-section. respectively, are close in frefuency. Moxles for these frequencies have very close molal foritions. Noso. the 12th muxte of the I-section isce Table 2) Was missed in the exprerimental survey which is indicative al the difficully of determining the high frepuency moles. The fact that anly one of the muliple experimential frecuencies with (lonse moxlal locations (moxle 9) is predicted hy the finite element maxlel may be altributed to imperfections in lamination and material properties: and/or to geometric monlinearities which were not incorporaled into the finite element moxlel. In lïgs. $5(b)$ and $1(n(b)$ bar charts are given for the frequencies ohtained by wo-dimensional muxlels of the actual and nominal fancs aloug with those of the one-dimensional moxlel.

In ligss. 6 and 11 har charts are given showing the two decompositions of the complementary strain energies, associilted with the different vihration moxles, described in the preceding subsection. The ordinates in Figs. (o(a) and 11(a) represent the rattios of $U_{1} / U^{c}, U_{2} / U^{c}$ and $U_{3} / U^{c}$, and the (ndinales in Figs. $(h(h)$ and $l /(h)$ represent the ratios $U_{1}, / U^{c}, U_{w}, U^{\circ}, U_{h r} / U^{c}$ for each of the moxles.

The mole shapes associated with the first five ex- perimental and analyticnl frequencies are shown in Figs. 7 and 12. Two views are shown for the deformations associated wilh each inode: side view and lop view. Also shown are the nodal lines of the $w^{\prime}$ displacenent on the top and bottom flanges. $\Lambda$ s can be seen from Figs. 7 and 12, the deformation patterns assoxiated with higher nodes are fairly complex. As mentioned previously, the only experimental nodal lines inonitoreal are those associated with gross in-plane, and gross out-of-plane molions. Generally, good agreement hetween the finite element and experimental nodal lines is observed in these cases. Other nodal lines, associated with localized deformations are shown only for the finite element solutions.

The sensitivities of the vibration frequencies to the fiher orientation angles of the top flange, web, and bottom flange and skin are depicted in Figs. 8 and 13. The ordinates in Figs. 8 and 1.3 represent the sensitivity derivatives with respect to the indicated fiher angles. Each of the sensitivity derivatives is nomalized hy dividing it by the corresponding frecfuency of vibration. The sensitivities of the vibration frepuencies of the material parameters $F_{1}, F_{1}, C_{1}$ and $G_{11}$ are shown in ligs." and 14. The ordinates in Figs. 9 and 14 represent the sensitivity derivatives with respect to the indicalled elastic moxhluli. Eich of the sensitivity derivanives is divided by the correspmenting frequency and multiplied by the corresponding elastic moxfulus. The effects of houndary comblitions on the frepuencies obtained hy the two-dimensional finite element models are shown in Tables 2 and 3.

An examination of the experimental and finite element results (Figs. 5 to 14 and Tables 2 and 3) reveals:

1. Reasonably good correlation is observed between numerical simulation and experiment for the l-section frame (see Fig. 5(h)). The ratios of the first five experimental frequencies to the corresponding finite element ones ranged hetween $(1.92$ and 1.02 (see Table 2). For the I-section framle the correlation is not ats goot (Fig. I(h(h)). The corresponding ratios for the first five freguencies were 0.87 w 1.04 (see Tilhle 3).

2. Most of the experimental frequencies for the I-section, frame and the $\mathbf{J}$-section frame are hetween those for the lotally and partially clamped supports (with borh $\phi_{2}$, and $\|_{1}$ - in lle flanges not res(rained). This is particularly true for the higher. modes. For some of the nodes the experimentul frecpuencies are closer to the partially clamped support case (e.g.. nxules III, $\mid 1$ and 12, see Fig. 5(b)). For the $I$ and $J$-section frames the finite element moxtel predicted only one of the multiple ex-. perimental frequencies with close nolal lines (mode 9). The. other experimental frequencies were hetween those for the tolally and partially clamped supports (with both $\phi_{2} \cdot$ and $\|_{1}$ - in the flanges not restrained, see Fig. I(h(h)).

3. The lowest five frepuencies ohtoined by the onedimensional model are reasonably close to those obtained by the corresponding two-dimensional nodel. This is particularly true for the J-heam where the errors in the predictions of the one-dinensional model were well below 10\% (see Figs. 5(il) and I(k(1)). 
4. Ilentificanion of the modes as in-plane or out-of-plane can thest he accomplished hy examining the energy components. $\mathrm{U}_{1} / \mathrm{U}^{\circ}$ and $\mathrm{U}_{2} / \mathrm{U}^{*}$. associated with the in-plane and out-of-plane forces, respectively (Figs. $6($ in) and II(a)). Alson. the error to he expected when using one-dimensiomal thinwalled heams can he estimated by computing the rallo of the energy associalled will the forces neglected in lhin-walled

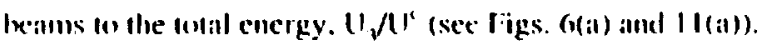

5. The coupling helween in-plane and oul-of-plane defomations is more pronounced in the J-section than in the I-section frame. As an example. the first twenty modes for the 1 -section frame had either $\mathrm{U}_{1} / \mathrm{U}^{\prime \prime}$ or $\mathrm{U}_{2} / \mathrm{U}^{\circ} \geq 0.75$. On the other hand, only modes 1 to $4,6,8$ and 10 in the J-section frame had $U_{1} N^{c}$ or $U_{2}, N^{c} \geq 0.75$. For the higher modes neither the ratio $U_{1} / U^{\circ}$ nor $U_{2} / U^{\circ}$ was close to 1 isee Figs. (o(a) and I ( (a)).

6. For the I-section frame, the contributions to the total energy of the lop and totlom flanges far exceeded that of the web for any given moxle. The ratio of the strain energy in the web to the lotal strain energy was less than 0.20 for the first ten muxles and less than 0.28 for the succeeding ten moxles isee Fig. $6(b))$. For the J-section frame the strain energy in the web inproinched to.4 of the totil energy in some of the modes (see IFig. 1 /(h)).

7. For the I-section frame, the strain energy of the top flange is the dominant energy in the in-plane deformation moxles and the strain energy of the hollom llange (including the skin) dominates for the out-of-plane deformation moxles (see Fig. (h)t).

8. The vibratimal response of both the I-section and J-section frames is very sensitive to restraining the $\|_{1}$ displacements of the flanges (and skin). It is somewhat sensitive to the rotational restraint on $\phi_{2}$. (see Tahles 2 and 3). Ilowever. it is insensilive $o$ restraining the displacemen components ${ }_{2}$, and $w^{\prime}$. and the rotition $\phi_{1}$.

9. The vihational response of the I-section and J-section is mure sensifive to variations in the $+45^{\circ},-45^{\circ}$ fiber angles of the lop flange than to varialious in the $0^{\circ}$ or 9()$^{\circ}$ fiter angles. The varialions in the $10^{\circ}$ and 9()$^{\circ}$ filners of the weh and the Ixiftom flange have a morceathe effect on some of the moxles. hut their effect is generally less thinl thatl of the $45^{n} .-45^{n}$ fihers (see liggs. 8 and 13 ). The vihrational response is also more sensitive to variations in the elastic moluli $F_{\text {, }}$ and $\left(i_{1}\right.$, than fo any of the wher material coefficients (see Figss. 9 and I4).

11. The sensitivity of the vibralion frecuencies with respecl lo varialions in both $F_{1}$ and $G_{1,1}$ is almost the same for all the moxtes (see Figs. 9 and 14). This may he attributed to the (uansi-isotropic lamination used for both the flanges and the weh. It suggests the rensibility of replacing the yuasi-isotropic composite, in the one-dimensional thin-walled beam nodel, by an equivalent isotropic material, as was done in the present stully.

\section{Comments on Sources of Errors}

\section{Sources of Errors}

The determination of natural frequencies and moxles from vibration tests and numerical models involves numerous mossible sources of discrepancies or errors which are related to mechanical and ecpuipuent limitations as well as to theoretical and physical assumptions. The errors in vibration tests include inexact equipment calibration, excessive noise, manufacturing variations, incorrect transducer locations and operation in a region of nonlinearity of the response. Numerical moxleling errors can he attributed to inaccuracies in estimated material properties and insufficien modeling detail. In the present study care was exercised in collecting and recording the vibrallon test data, and in the selection of the numerical noklel. llowever, nominal material properties and layups (fiher orientation of the different layers) were used in the numerical model. The sensitivity analysis helped in identifying the miterial and Iamination parameters that need to be accurately deternined.

\section{Concluding Remarks}

$A$ detailed study was made of the effects of variations in lamination and matterial parameters on their vibrational claracteristics of thin-walled composite frames. The structures considered are semicircular, thin-walled frames with 1 and $J$ cross sections. The hanges. web and skin of the stiffeners have yuasi-isotropic laminations with filer orientation being combinations of $\pm 45^{\prime \prime}$. ()$^{\prime \prime}$ and 9()$^{\prime \prime}$ layers. Two compuntalional models are used for predicting the vibrational characteristics. In the first moxlel, the flanges and wehs of the stiffeners were muleled by using two-dimensional shell (and plate) finite elements. The second moxiel was a finite element discretization of the one-dimensional Vlasov's-type thin-walled beam theory. A nixed formulation was used with the fundimentil unknowns consisting of both the generalized displacements and siress resultants (or intermal forces) in the frame. The freyuencies and moxles predicted by the computational moxtels are compared with those obtained from experiments. $\wedge$ detailed study wiss made of the sensitivity of the vibrational response to vatriations in the fither orientation, material propetties of the individual layers, and boundary conditions. On the hasis of this studly the following conclusions are justified:

1. For some of the higher vibration noxles the experimental frequencies for thin-walled frames are generally between those for the totally and partially clamped suppoits.

2. Identification of the modes as in-plane or out-of-plane can hest he accomplished by examining the energy components associated with the in-plane and out-of-plane forces. Also, the mininum error to be expected when using one-dimensional thin-walled beillus can be estimated by computing the rattio of the energy associaled with the forces neglected in thin-walled beams to the total energy.

3. For yuasi-isotropic composite frames the vibration frequencies, associated with the lower modes, can he accurately predicted by isotmpic one-dimensional beam model (with effective elastic moduli). The accuracy of predictions is 
dependent on the conss-sectional distortions during the beam defomations. As the cross-sectional distortions increase, the degrialation of accuracy hecomes more pronounced.

4. The vibrational response of thin-walled semicircular frames is very sensilive to restraining the displacement compoItent of the flanges along the length of the frame. It is somewhat sensitive to the restrain on the associated rotational component. However, it is less sensitive to restraining the olher displacement and rotation components.

5. The vihrational response of thin-walled composite frames with fuasi-isofropic laminations is more sensitive on variations in the $+45^{\prime \prime}$. $-45^{\prime \prime}$ filoer angles of the Iop Hange than In variations in the 10 " or 90 " fiter angles. Variations in the $01 "$ and "(1" filers of the web and the bottom flange have a moliceable clfect on some of the moxies, but their effect is generally less lhan that of the $45^{\prime \prime}$. $-45^{\prime \prime}$ fihers. The vibrational response is also more sensitive to variations in the material coefficients $E_{1}$ and $i_{1,1}$ than lo all other coefficients.

6. The sensitivity of the vibration frequencies with respect lo varialions in buth $E_{1}$ and $G_{1,}$ is almost the sane for all the moxles. This may be altributed to the quasi-isotropic lamination used for both the flinges and the weh. It suggests the feasibility of replacing the curasi-isotropic composite by an equivalent isotropic material in the one-dimensiomal thinwalled heam analysis, as was done in the present study.

\section{References}

1. Boituont. R. L.. Fasanella, F. L., Callon, L. E. and Carden, H. D.: Impact Response of Composite Fuselage Frames. Terhmical Paper Series No. 89l(x). The Engineering Society for Advancing Mobility. Land. Sea. Air, and Space, Warrendale. PA, April 1987.

2. Builuolt, R. L. and Fasanellat, E. L.: Impact Evaluation of Composite Flowr Sections. SAE Terdmical Paper Series No. 89lols. The Engineering Soxiely for Advancing Mohility, I and, Sea, Air. and Space,. Warrendale. PA, April 1989.

3. Collins. J. S. and Jolunson. E. R.: Static and FreeVibmational Response of Semi-Circular Graphite-Epoxy Frames with Thin-Walled Open Sections. Report CCMS89-21. Center for Composite Materials and Struclures. Virginia Polytechnic Institule and State University. Blicksburg. VA, October 1989.

4. Chamdra, R., Ngo, If. and Clwopra, I.: Experimental Study of Thin-Walled Composite Beams. Procededings of the

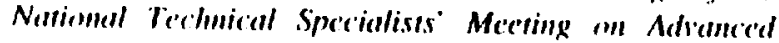
Romerraft Strumes.s. Oct. 25-27. 1088. Williamshurg. VA. Americin Helicopter Soxiety, 1988.

5. Vlasov, V. 7. (Y. Schechtminn, transl.): Thim-llalled Flasfir Bremms. Isratel Program for Sciendific Tramslations. 1)(1).
6. Cijelsvik, A.: The Theory of Thin Walled Bars. John Wiley \& Sons, Lid., 1981.

7. Nowinski, J. L.: Theory of Thin-Walled Bars. Applied Merhemics Survess. H. Nomman Abramson, Ilarold Liebowiz. Joln M. Crowley and Stephen Juhiasz, eds., Spartan Books, 1966, pp. 325-338.

8. Pamovko. Ya. G.: and Beilin, E. A.: Thin-Walled Beams and Systems Consisting of Thin-Walled Beams. Srrm unral Mechemises in the USSR - 1917-1967. I. M. Rabinovich, ed., Muscow Puhl. IInuse, 1969, pp. 75-98 (in Russian).

9. Hasam. S. A. and Barr, A. D. S.: Linear Viluation of Thin-Walled Beams of Eyual Angle-Sectimu. I. Sommd of librotion, vol. 32. Jin. 1974. pl]. 3-23.

10. Vermishian, G. B.: Torsion of a Viscoelastic Prismatic Composite Rol Under the Action of a Vibrational Lond. Akerdemiia Nomk Armiemskori SSR. Iziestiia. Mekhomika. vol. 27, mo. I, 1974. pp. 48-62 (in Russiaun).

11. Rao. C. K.: Nonlinear Torsional Vibrations of IhinWalled Beams of Open Section. I. Appliced Merhmics. vol. 42, March 1975. p1). 24()-242.

12. Vasilenko. N. V. and Trivailo, P. M.: Viluration of Thin-Walled Roxls with Open Profile of Material will Nomlinear Hysteresis. Prohlamy Prochnosrti. Nov. 1979 pp. 72-76 (in Russian) (Finglish translation in Srength of Materials, vol. 11, no. 11, July 1980. p1). 1279-1285).

13. Narayanan, S., Mallik. А. K. and Verma, J. P.: Free Vihration of Thin-Walled Open Section Beams with Unconstrained Damping Trealment. J. Appl. Mech., vol. 48. March 1981. pp. 169-17.3.

14. Ali, S. A.: Stability of Bending-Torsional Vilmations of Curved Thin-Walled Reams, I. Sormel of $1 \mathrm{ih}$. vol. 95. Alte. 198. pr. 341-3.50.

1.5. Gupti, R. K.. Venkillesh, $\Lambda$. and Ralo, K. D.: linite Element Analysis of Laminated Anisotropic Thin-Walled Open-Section Beauns. Compmsite Siructure's, vol. 3. 1985. pp. 19-31.

16. Potiron, A.. Gay, D., Czeknjski, C. and I inRoze. S.: I.imitation of Simplified Hymotheses for the Prediction of Torsional Oscillations for Thin-Walled Beams. I. Vibration. Aconstics, Stress \& Reliability in Design, vol. 107. Jan. 1985. pp. 117-122.

17. Rikkschloss, J. and Tesar, A.: Transfer Matrix Fonmula. tion for Solution of Torsion-Bending Vihraltion of Beams with Thin-Walled Cross Section. Acra Terhnica CSAI, vol. 31). no. 5. 1985. pp. 524-5.38.

18. Wekezer, J. W.: Free Vibrations of Thin-Walled Bars with Open Cross Sections. I. Eng. Mech., vol. 113, no. 10, Oct. 1987, pp. 1441-1453. 
19. Rehficld, L. W., Hoxlges. D. II. and Atilgan, A. R.: Some Considerations on the Nonclassical Behavior of ThinWalled Composite Beams. National Technical Specialists' Meeting on Advanced Rotorcraft Structures. Proc. (x). 25-27, 1988, Williamshurg. VA, American Helicopter Society, 1988.

20. Stemple, A. D. and Lee, S. W.: Finite-Element Moxtel for Composite Beams with Arbilrary Cross-Sectional Warping. AIAA Leurnel, vol. 26. Dec. 1988. pp. 1512-1520.

21. Mishop, R. E. D.. Cammon. S. M. and Mian, S.: On Compled Bending and Torsional Vibration of Uniform Reauns. I. Sround \& V'ibration, vol. 131, June 1989. pp. 4.57-464.

22. Teh, K. K. and Huang. C. C.: The Effects of Fibre Orientation on Free Vibrations of Composite Beams. $I$. Sontul \& librotion, vol. 69. March 19811, pp. 327-3.37.

23. Hank. L. C. and Kao, C. H.: The Influence of Cieometric and Malterial Design Variables on the Free Vibrallion of Thin-Walled Composite Material Beams. Jommal of libration. Aconstics. Stress and Reliahility in Designn. vol. 111. July 1989. pp. 29(1-297.

2.4. Nentr, A. K., Carden, II. D. and Peters, J. M.: Free librations of Thin-lialled Semicirchlor Giraphite-Epoxy composite Frames. NASA TP-3010, 1990.

25. Nexrr, A. K., Peters. J. M. and Min, B. J.: Mixed Finite Ele'me'm Models for Free Vibrations of Thin-Walled Beamis. NASA TP-2808, Feb. 1989.

26. Nomr, A. K. and Andersen. C. M.: Mixed Models and Reduced/Selective Integration Displacement Models for Nonlinear Shell Analysis. Int. I. Nomer. Methods Eng.. vol. 18. no. 10. Oxt. 1982, pp. 1429-1454.

27. N(x)r, A. K. and Pelers, J. M.: Mixed Models and Re duced Sclective Integration Displacement Models for Vibration Analysis of Shells. Hrbrid and Mixed Finite Fle'mo'nt Mo'thods, S. N. Athri, R. H. Gallagher and O. C. Zienkicwic7. eds., John Wiley \& Sons, 198.3, pp. 537-564.

28. Nelsmm. R. B.: Simplified Calculation of Eigenvector Derivatives. AIAA Jommul, vol. 14, 1976, p). 1201-1205.

21. Jones, R. M.: Merhanics of Composite Materials. Hemispliere Puh. Co.. New York, 1975.

31). (ingelle, I. P.: An Improved Subrouline for the Estimafinn of Torsional Properties of Thin-Walled Open Cross Sections, Eng. Comput. vol. 4. no. 3. Sept. 1987. pp. 2411-242.

31. Chen. J. C. and Ciarba, J. A.: Matrix Perturbation for Analytical Moclel Improvement. Proceedings of the AIAAIASMEIASCEIAHS $201 \mathrm{~h}$ Siructures, Sirnctural Druamics and Materials Conference. A Collection of Techmical Papers on Dymomics and Lads. April 4-6. 1979. St. I nuis, MO, pp. 428-4.36.
32. Crawley, E. F. and Jensen, D. W.: Frequency Detennination Techniyues for Cantilevered Plates with BendingTorsion Coupling. AIAA Journal, vol. 22, March 1984, pp. 415-420.

33. Ewins. D. J.: Modal Testing: Theory and Practice. Resenrch Studies Press, John Wiley \& Sons, Lid., 1984.

34. Falco, M. and Gasparetto, M.: Flexurat-Torsional Vihralions of Thin-Walled Beans. Meccanica, vol. R. Sept. 197.3. pp. $181-189$.

35. Arruda, J. R. de F.; and Simolos, J. M. C. dos: Moxdel Adjusting of Structures with Mechanical Joints Using Modal Synthesis. Procecdings of the Seventh International Modal Andysis Conference, Jan. 30-Feb. 2. 1989. Lals Vegas. NV, vol. I. Sociely for Experimental Mechanics, Inc., Bethel, CT, 1989, pp. 850-856.

36. Baruch, M.: Optimal Correction of Mass and Stiffness Mattrices Using Measured Modes. AlAA Journal, vol. 20 . no. 11, Nov. 1982, pp. 1623-1626.

37. Berman, A.: Mass Matrix Correction Using an Incomplete Set of Measured Moxtes. AIAA Journul, vol. 17, nu. 11, Oct. 1979, pp. 1147-1148.

38. Berman, A. and Wei. F. S.: Antomated Dinamic Andyrical Model limprove'ment. NASA CP-34.52, July 1981.

39. Bermain, A. and Nagy. E. J.: Improvenent of a Large Analytical Model Using Test Data. AIAA ,Inurnal, vol. 21. no. 8. Aug. 198.3, pp. $1168-1173$

40. Grossman, D. T.: An Auromaled Technicjue for Improving Modal Test/Analysis Correlation. Proceedings of the AIAAIASMEIASCEIAHS 23rd Sirucules, Struchural Dinamics and Materials Conference. Pant 2. A Collection of Tochnical Popers, May I(1-12, 1982, New Orleans, LA, pp. $68-76$

41. Jensen, D. W. and Crawley, E. F.: Comparison of Fre quency Determination Techuicues for Cantilevered Plates with Bending-Torsion Coupling. Procecedings of the

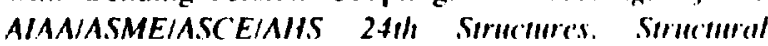
DVnemics and Materials Comference. Part 2. A Cibllection of Teclmic al Papers. May 2-4. 198.3. Lake Tahoe. NV. MP. 7.37-743

42. Kahe, A. M.: Stiffness Matrix Adjusumem llsing Mokle

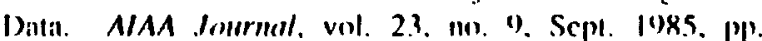
$1431-1436$.

4.3. Martinez. D. R. and Miller, A. K. (eds.): Commined EyperimentallAnolyrical Moleling of Dynamic Sirnutural Syrtems. Joint ASCE/ASME Mechanics Conference. Albucpuerque, NM. June 24-26, 198.5. ASME Publication.

44. Wei, F. H.: Stiffness Matrix Correction From Incomplete Test Dita. AIAA Iournal, vol. 18, no. I1), Oxt. I981), 12p. 1274-1275. 
1.5. Zhirohowski-Koscia. K.: Thin-Walled Beams - From $\mathbf{u}_{1}, \mathrm{u}_{2}, w$

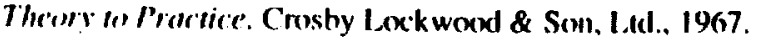

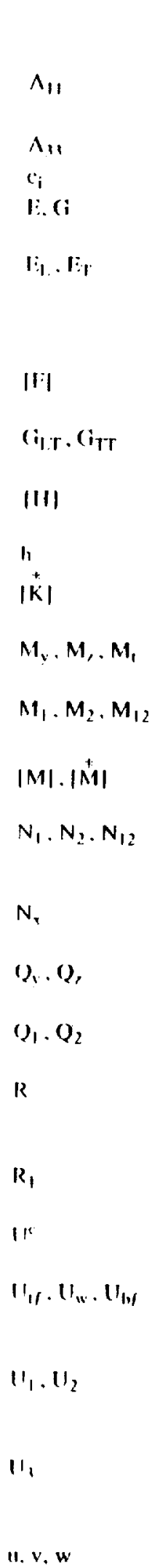

\section{APPENDIX $\wedge-$ Symbols}

extensional stiffiess of the laminate

(flanges or web) in the $x_{1}$-rlirecilion

in-plane shear stiffness of the laminate

multipliers (see Eys. 5 and 7)

effective Young's and shear moxduli of the equivalent isotropic material, respectively elastic monluli of the individual layers of the laminale (flanges or web) in the direction of fihers and normal to it, respectively

mattix of linear Mexibility coefficients for an individual element

shear monluli in the plane of fibers and normal to it, respectively

vector of stress resultant for internal furce) parianeters

total thickness of the laminate

generalized stiffness matrix for an individual element (see Eys. 3)

hending and twisting monents in the one-dimensional beamin mulel

bending stress resultants in the two. dimensional muklel

consistent and generalized mass maldices for an inclividual element (see Fuss. 3) extensional stress resultants in the twodimensionial morelel

axial force in the one-dimensional beam mondel

transverse shear forces in the one. dimensional heim moxiel

Imonsverse shear stress resultants in the Iwo-dimensional molel

raclius of curvalure of the centerline of the frame (used in one-dimensional beatm moxlely

outer radius of curvature of the frame (see

Fig. 1)

total complementary strain energy of the frime

contributions of the top flange, web and Ixottom flange (including the skin) to the total complementary strain energy

complementary strain energy components assexiated with in-plane and out-of-plane forces. respectively complententary strain energy component associated with the forces neglected in the one-dimensional beam model

displacement components in coordinate directions for the one-dimensional beam moxlel

$$
u_{1} \cdot, u_{2} \cdot w
$$

(X)

$x_{1}, x_{2}, x_{3}$

$|2|$

$\{\%\}$

$\theta$

$\lambda_{\mathrm{i}}$

$p$

$v_{1, T}$

$\phi_{1} \cdot \phi_{2}$

$\phi_{1} \cdot \phi_{2} \cdot \phi_{1}$

(1)

j)

Subscripts:

ID one-dimensional finite element moxlel

2D two-dimensional finite element model

$s \quad$ shear center

Stџrerscripts:

1 matrix transposition

Table 1.- Decomposition of total complementary energy, $\mathrm{U}^{\mathrm{c}}$ into components.

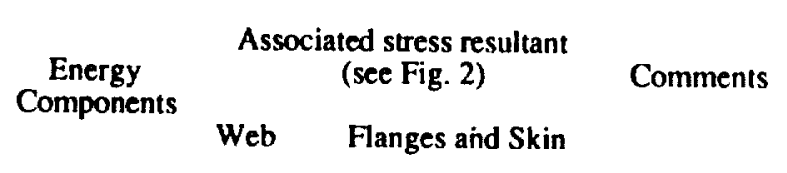

\begin{tabular}{cccc}
\hline $\mathrm{U}_{1}$ & $\mathrm{~N}_{1}, \mathrm{~N}_{12}$ & $\mathrm{~N}_{1}, \mathrm{M}_{1}, \mathrm{Q}_{1}$ & $\begin{array}{l}\text { in plane response } \\
\text { quantities }\end{array}$ \\
$\mathrm{U}_{2}$ & $\mathrm{M}_{1}, \mathrm{M}_{12}, \mathrm{Q}_{1}$ & $\mathrm{~N}_{12}, \mathrm{M}_{4}$ & $\begin{array}{l}\text { out-of-plane re- } \\
\text { sponse quantities }\end{array}$ \\
$\mathrm{U}_{3}$ & $\mathrm{~N}_{2}, \mathrm{M}_{2}, \mathrm{Q}_{2}$ & $\begin{array}{l}\text { response quantities } \\
\text { neglected in one- } \\
\text { dimensional model }\end{array}$ \\
\hline $\mathrm{U}^{\mathrm{c}}=\mathrm{U}_{1}+\mathrm{U}_{2}+\mathrm{U}_{3}$ &
\end{tabular}




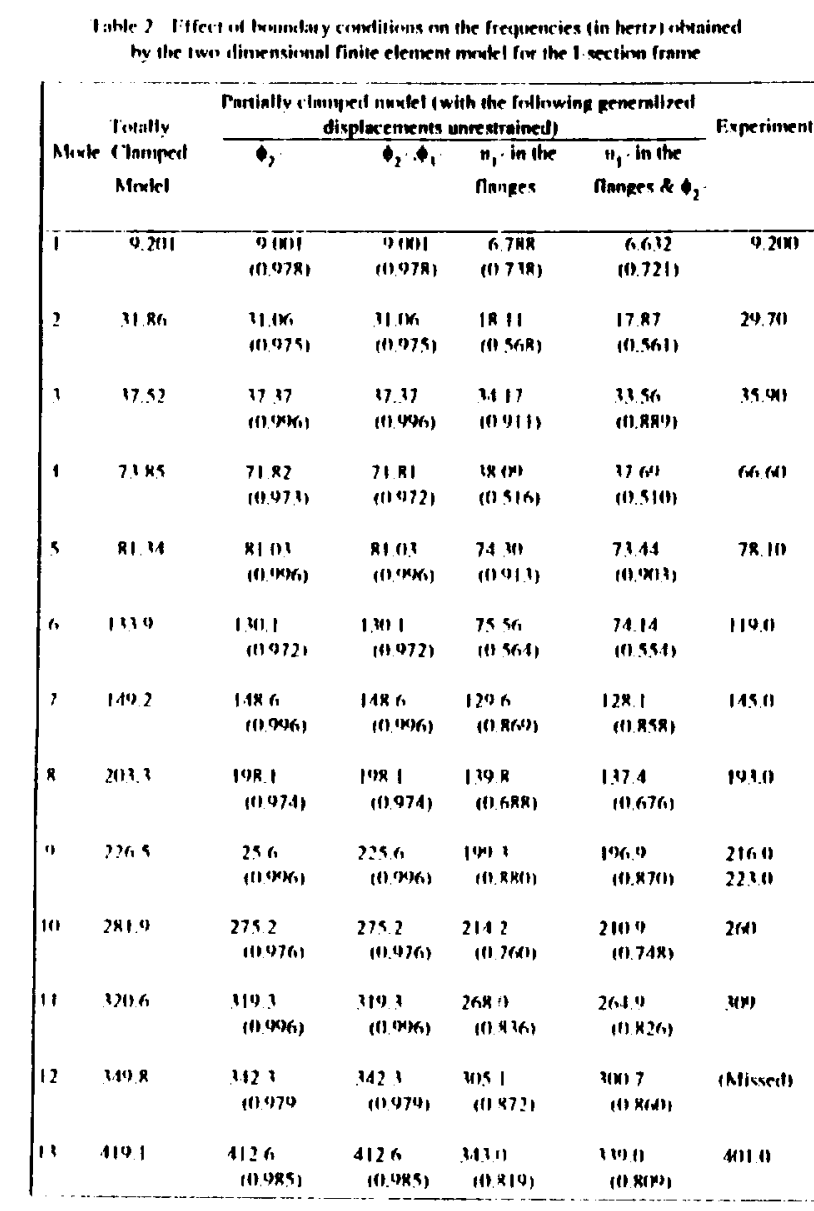

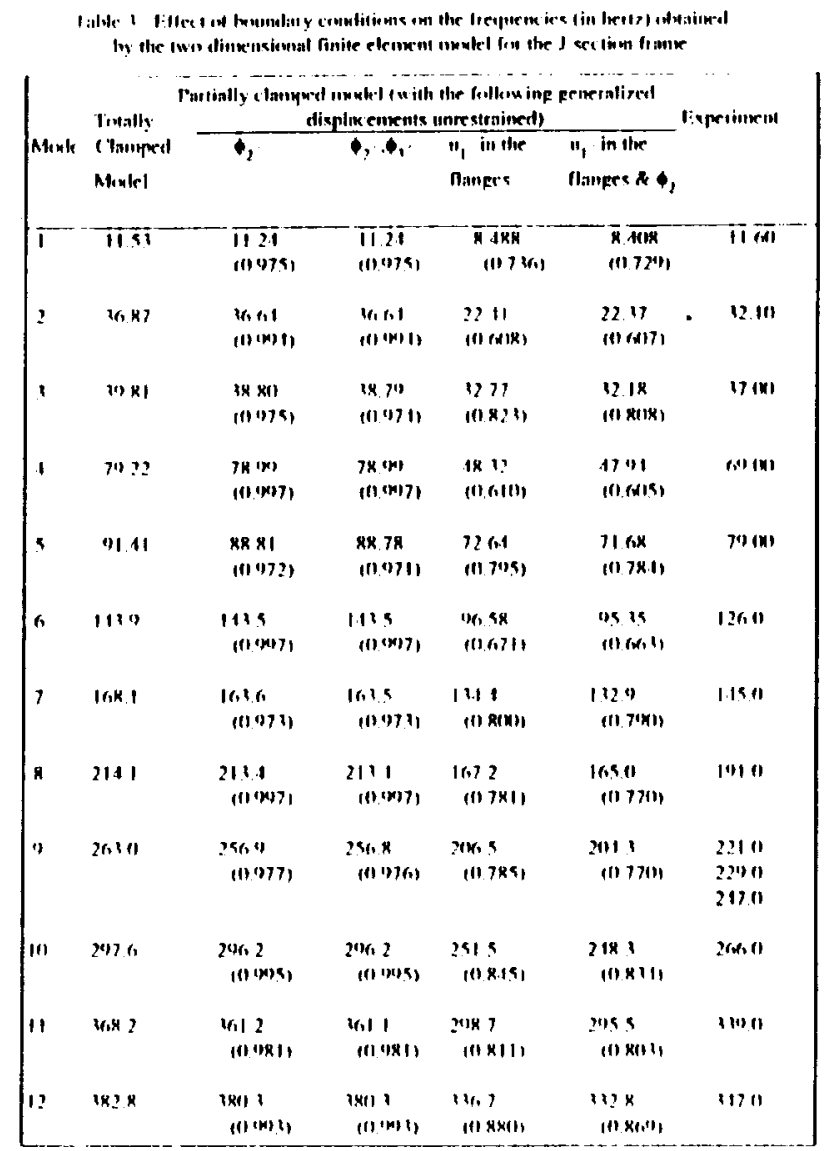

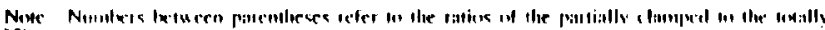

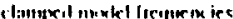

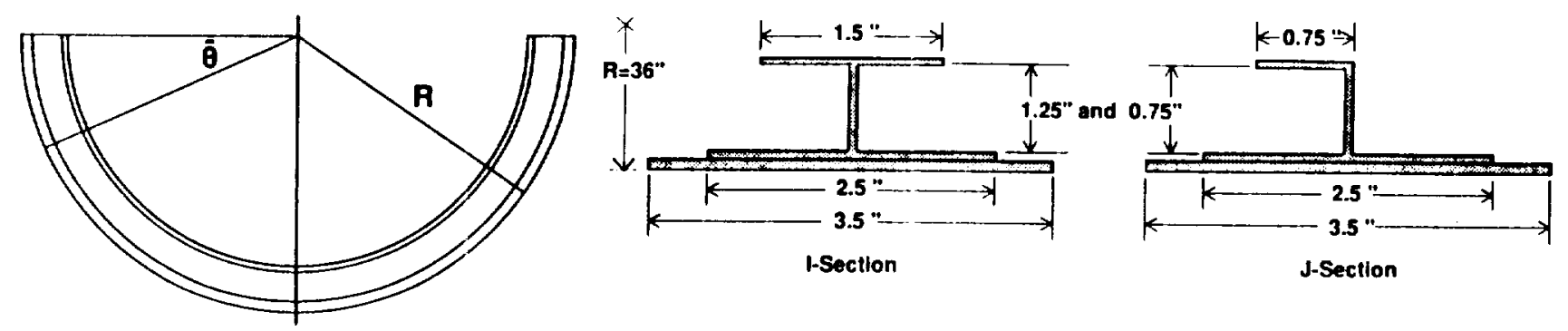

\section{Material Properties}

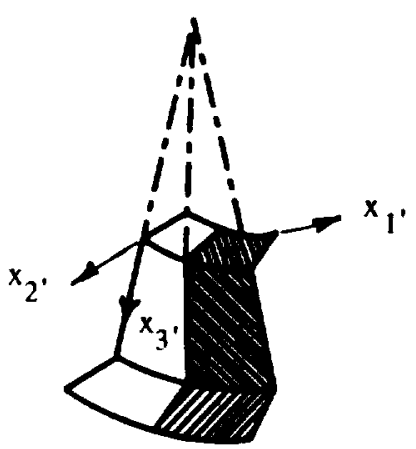

Global coordinate . system
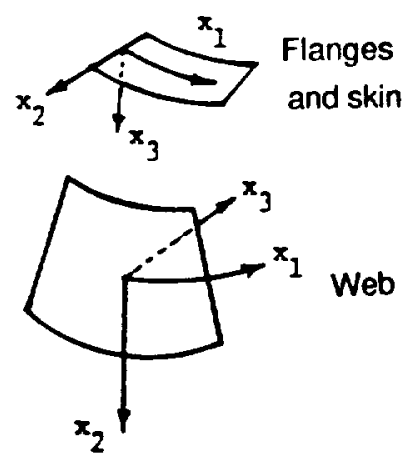

Local coordinate system
$E_{L}=2.0 \times 10^{7} \mathrm{psi}$

$E_{T}=1.7 \times 10^{6} \mathrm{psi}$

$G_{L T}=9.3 \times 10^{5} \mathrm{psi}$

$\mathrm{G}_{T T}=6.51 \times 10^{5} \mathrm{psi}$

$v_{\mathrm{LT}}=0.38$

$\rho=0.058 \mathrm{lb} / \mathrm{in}^{3}{ }^{3}$

Nominal layer thickness $=0.005$ in.

\section{Eiber Orientation}

$N L=8 \quad: \quad[ \pm 45 / 0 / 90]_{s}$

$\mathrm{NL}=16:[ \pm 45 / 0 / 90]_{2 s}$

Figure 1.- Thin-walled composite frames and coordinale systems used in present study. 

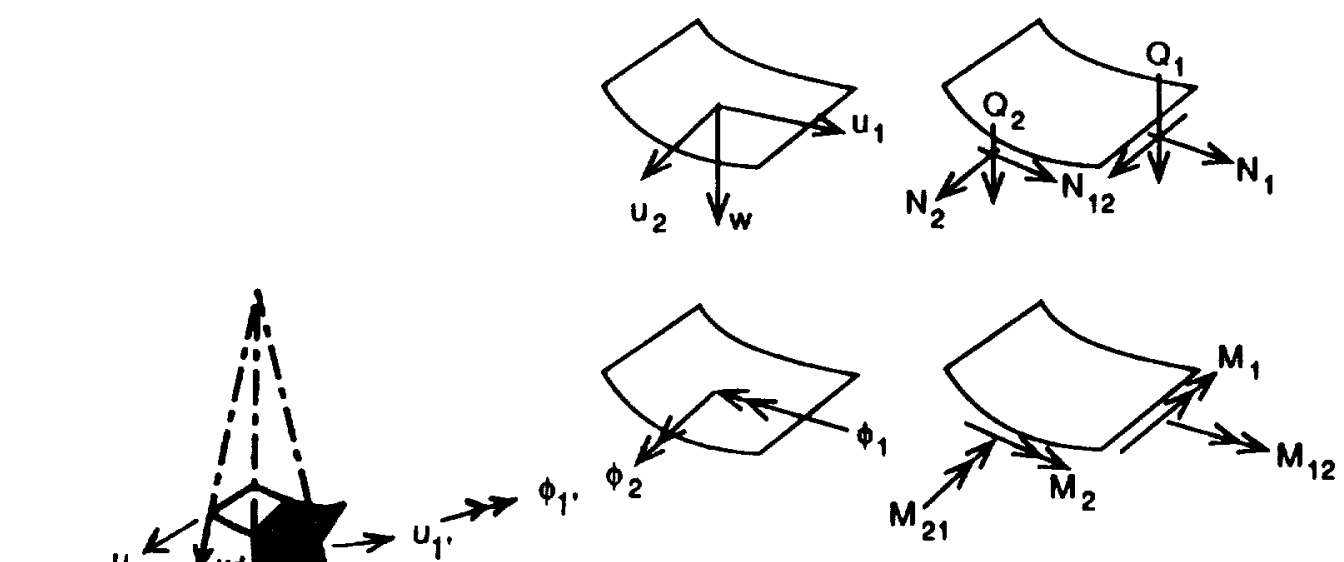

Flanges and Skin

Generalized Displacements Referred to Global Coordinates
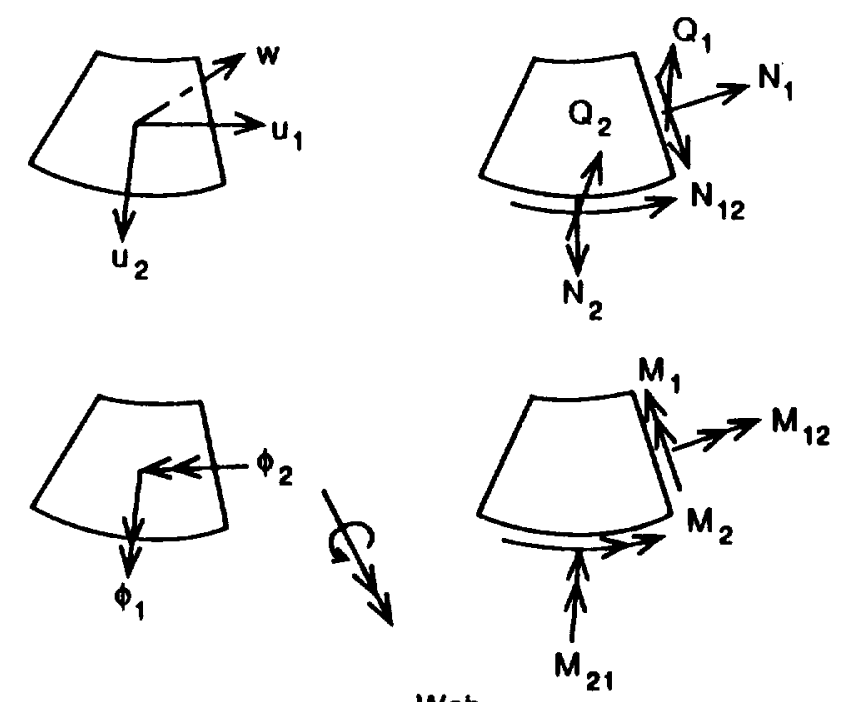

Web

Figure 2.- Sign convention for generalized displacements and stress resultants in two-dimensional model.
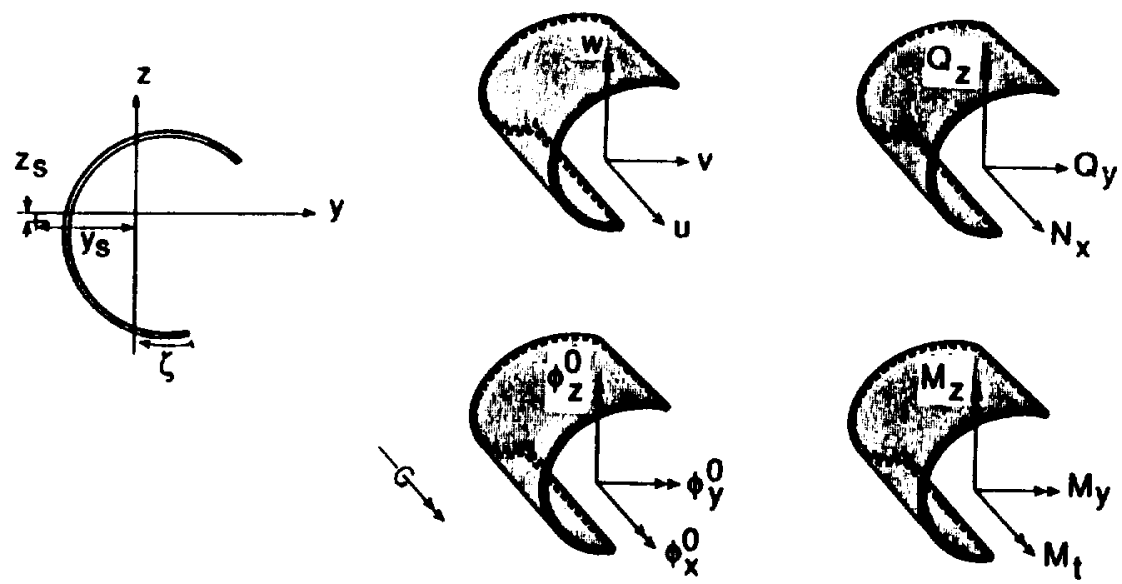

Figure 3.- Sign convention for generalized displacements and stress resultants for one-dimensional model. 


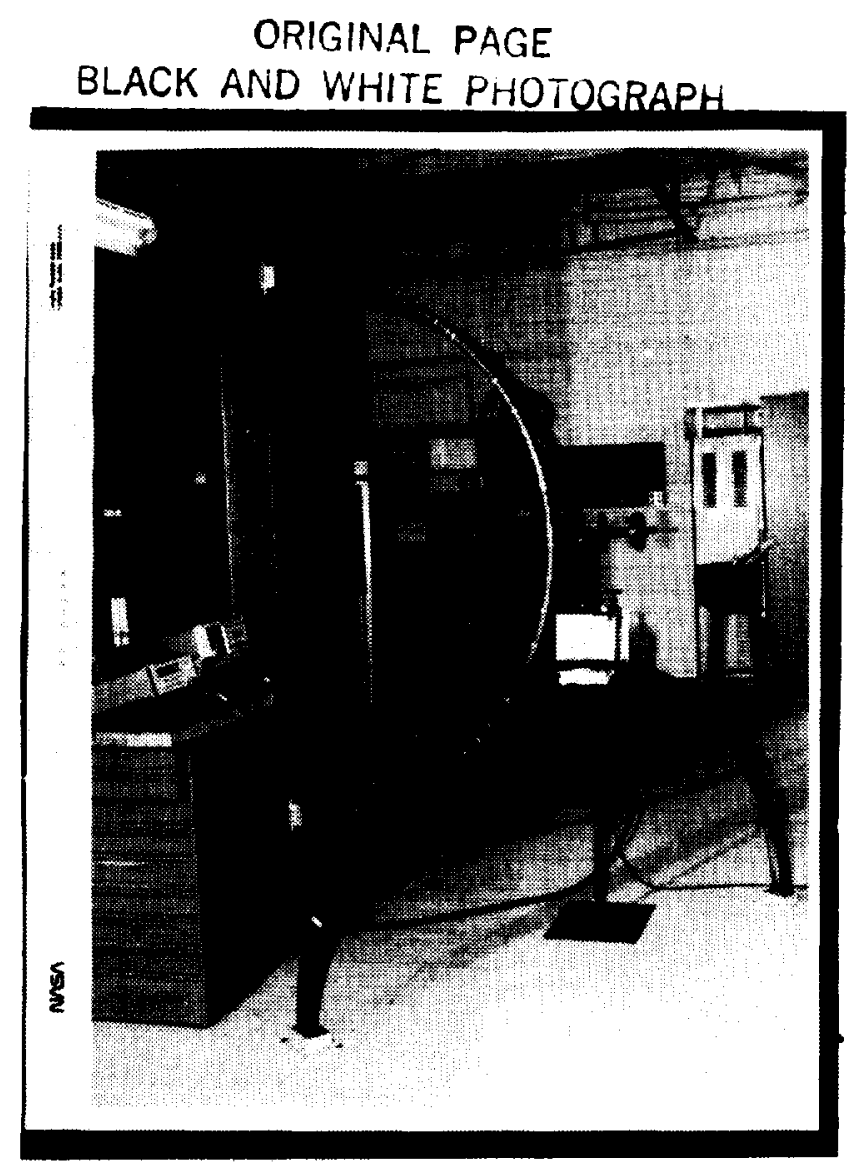

Figure 4.- Photograph of thin-walled semi-circular graphite-epoxy specimens and experimental equipment.

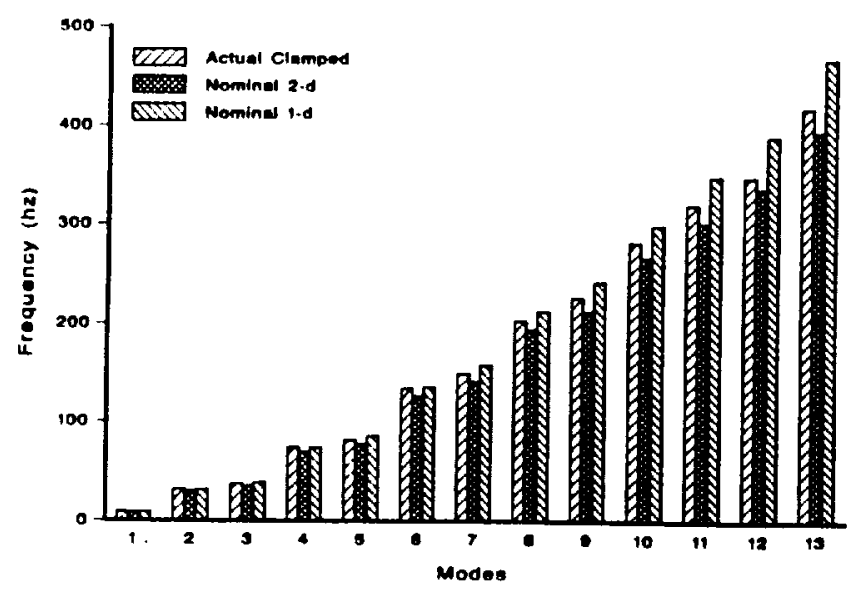

(a) Two-dimensional and one-dimensional beam model results.

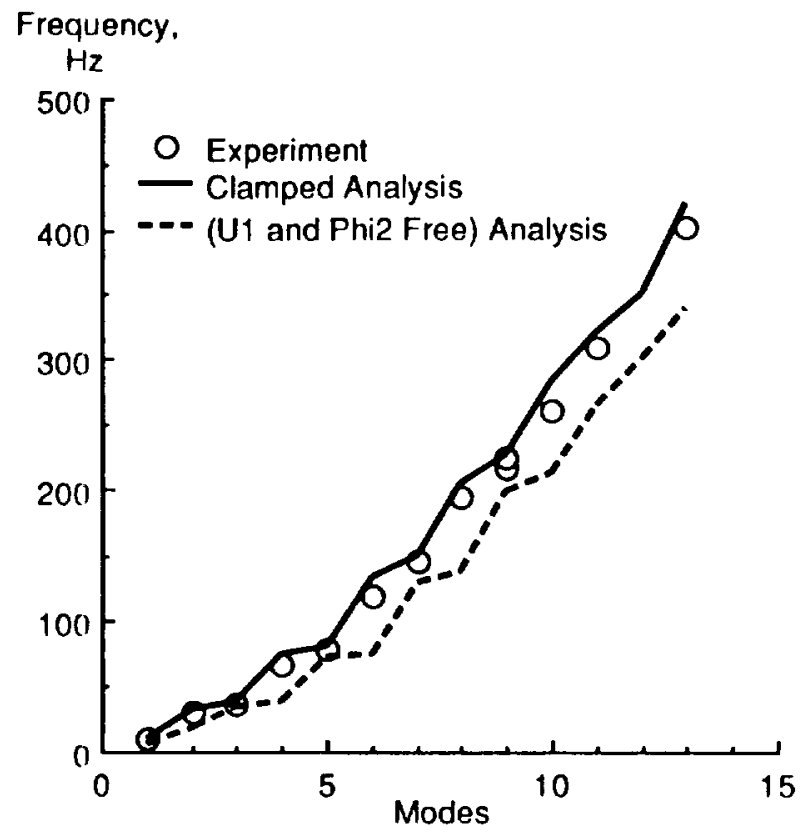

(b) Experimental and bounding two-dimensional model results.

Figure 5.- Comparison of finite element and experimental frequencies for the thin-walled composite frame with I cross-section.

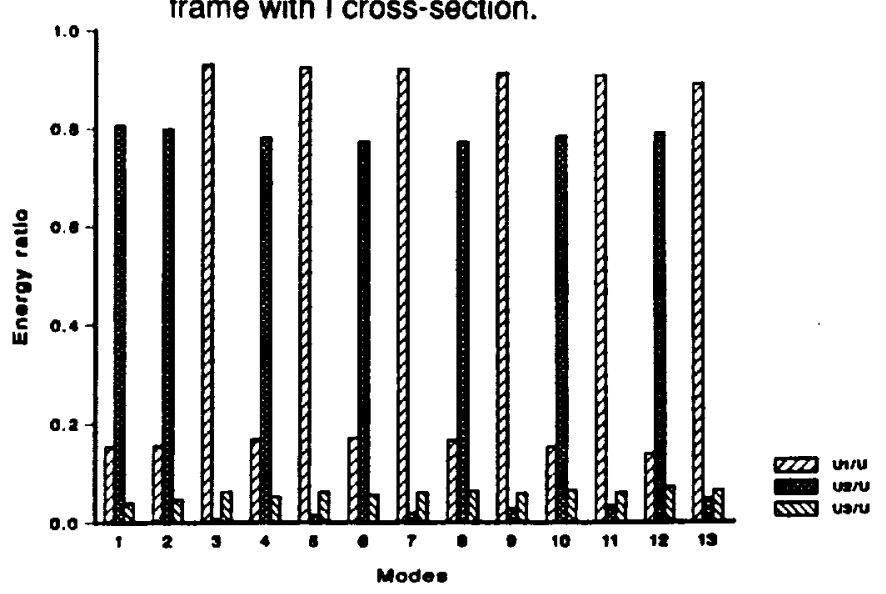

(a) $U_{1}, U_{2}$, and $U_{6}$ components.

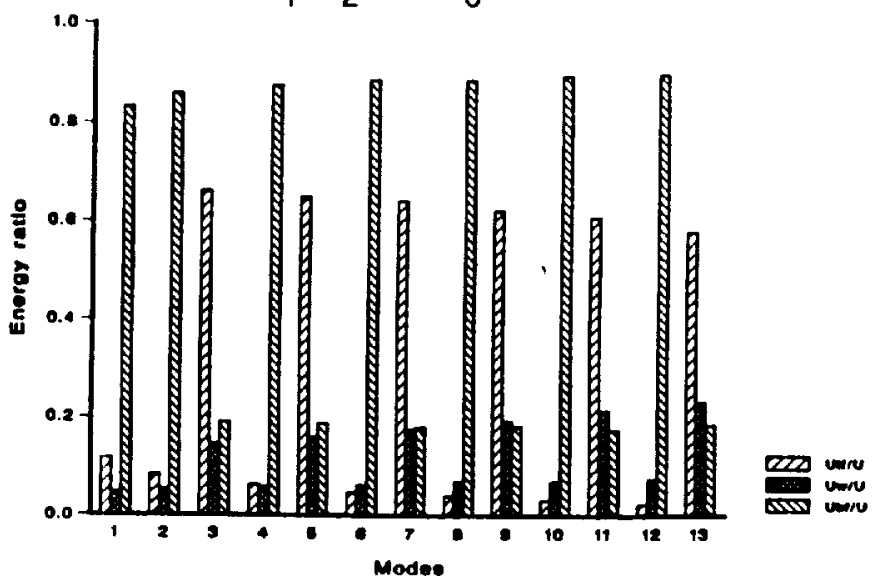

(b) $U_{t f}, U_{w^{\prime}}$ and $U_{b f}$ components.

Figure 6. - Energy components in the different vibration modes of the thin-walled composite frame with I cross-section. 
Top View

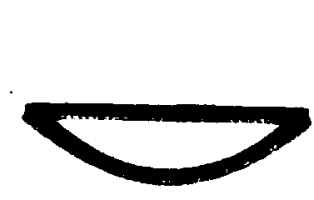

${ }^{(1)_{1}}=9.20(9.2) \mathrm{Hz}$

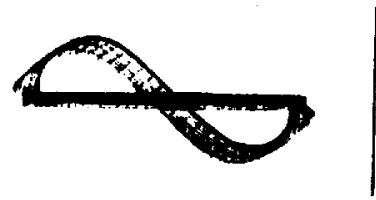

$(1)_{2}=31.9(29.7) \mathrm{Hz}$
Side View
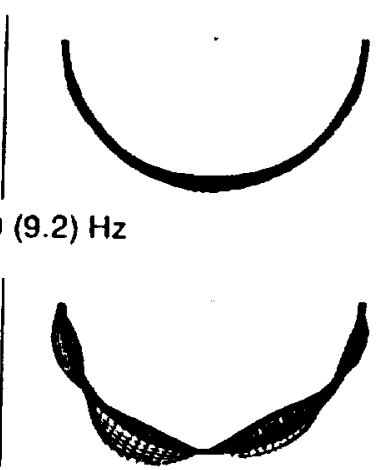

$(1)_{3}=37.5(35.9) \mathrm{Hz}$

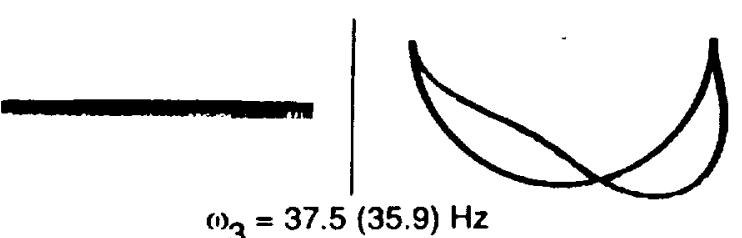

Nodal Lines on Top and Bottom Flanges

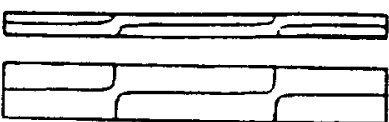

Experimental Node Lines (Bottom Flange)

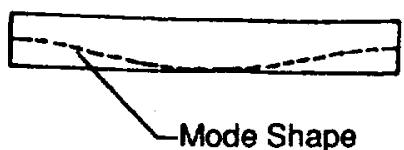

(See Analytical Top View)
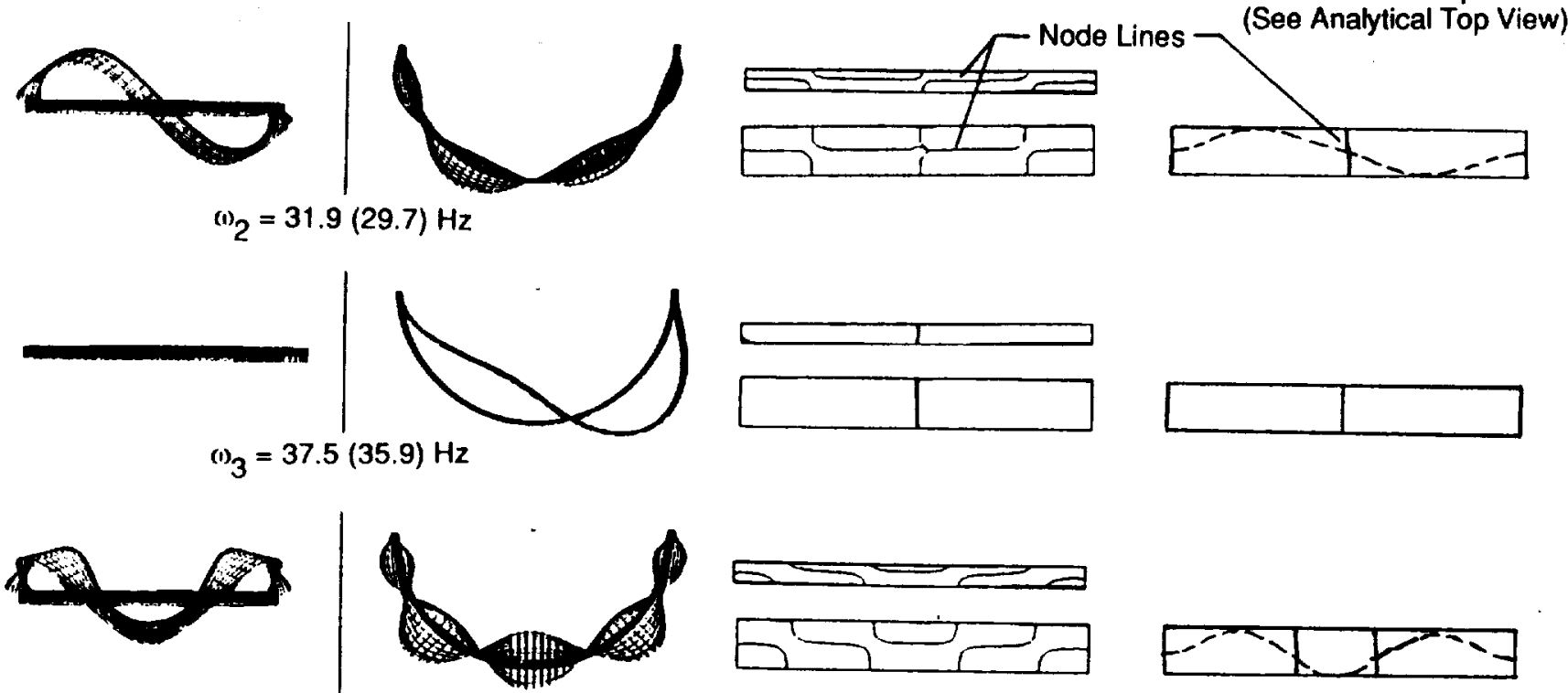

(1) $4=73.9(66.6) \mathrm{Hz}$
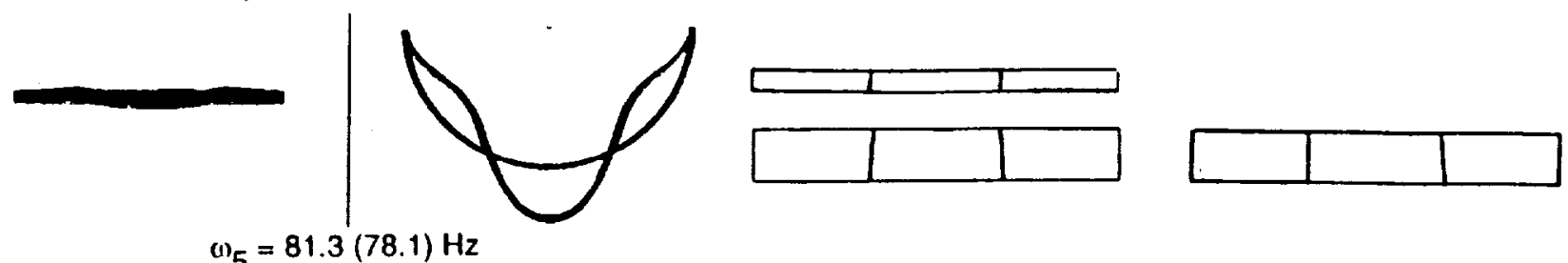

$\omega_{5}=81.3(78.1) \mathrm{Hz}$

Figure 7.- Mode shapes associated with the lowest five frequencies for the thin-walled composite frame with I cross-section. Parentheses are experimental frequencies. Others are clamped finite element model results. 


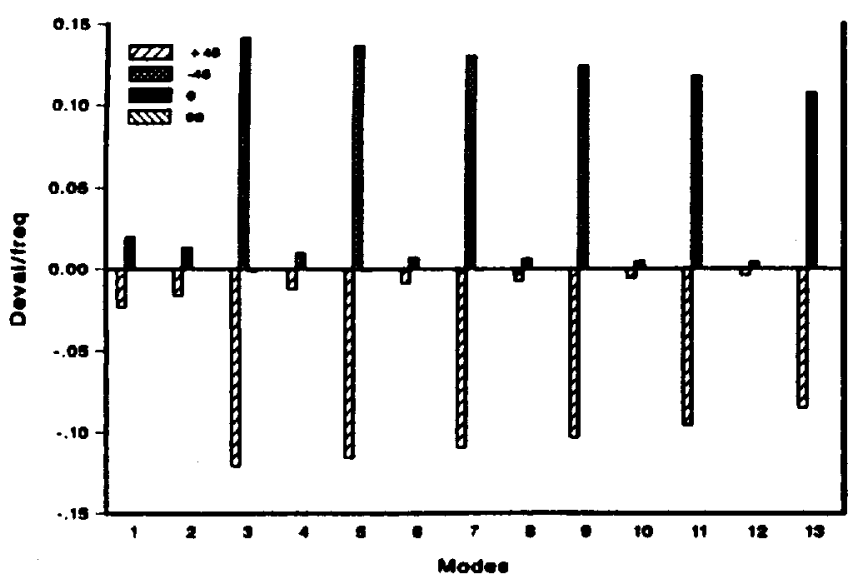

(a) Top flange.

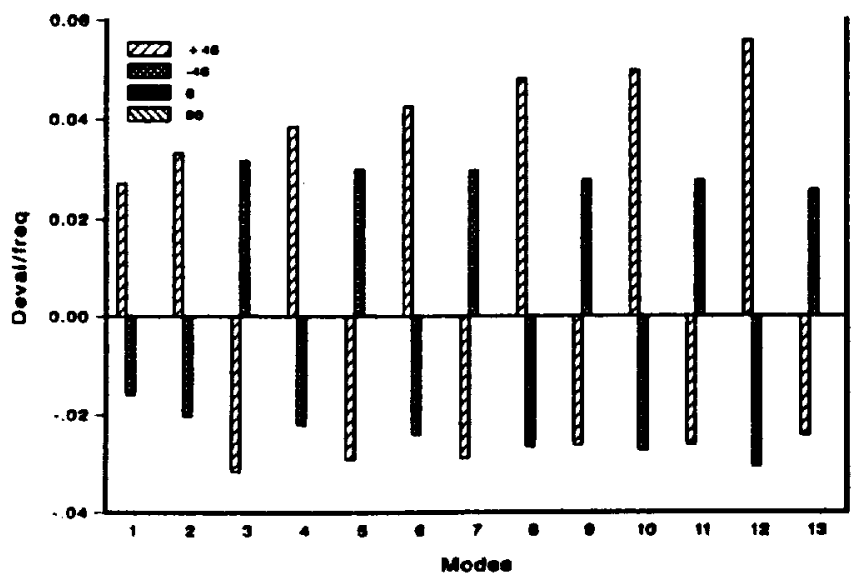

(b) Web.

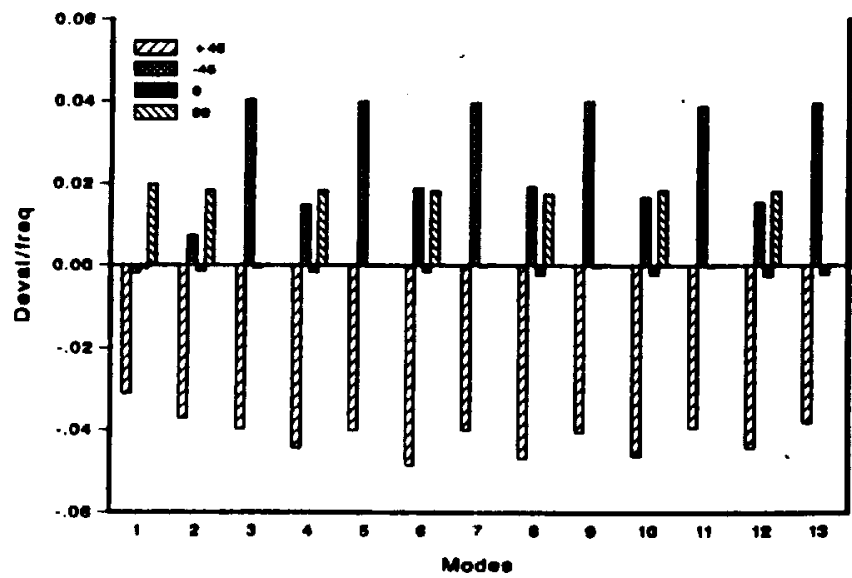

(c) Bottom flange and skin.

Figure 8.- Sensitivity of vibration frequencies to fiber orientation angle in the flanges and web of the thin-walled composite frame with I crosssection.

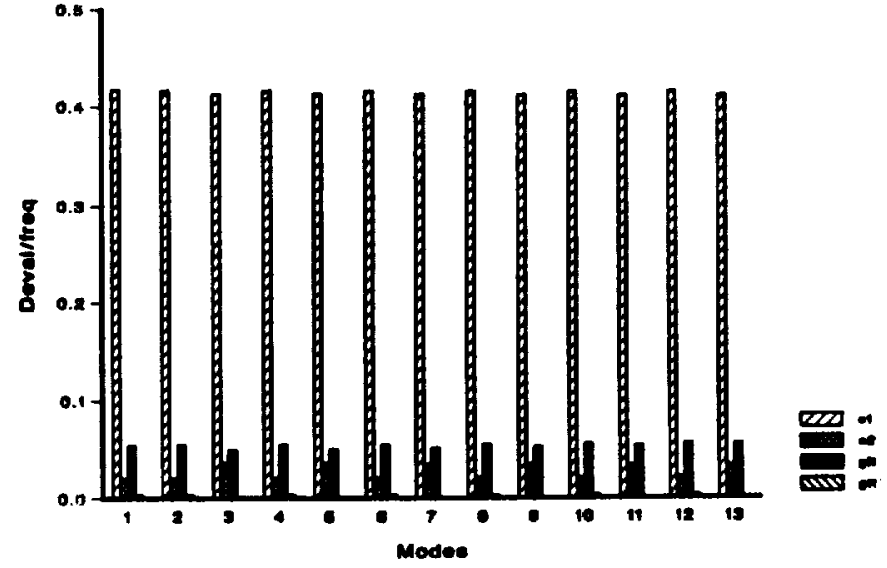

Figure 9.- Sensitivity of vibration frequencies to variations in material characteristics of the thin-walled composite frame with I cross-section.

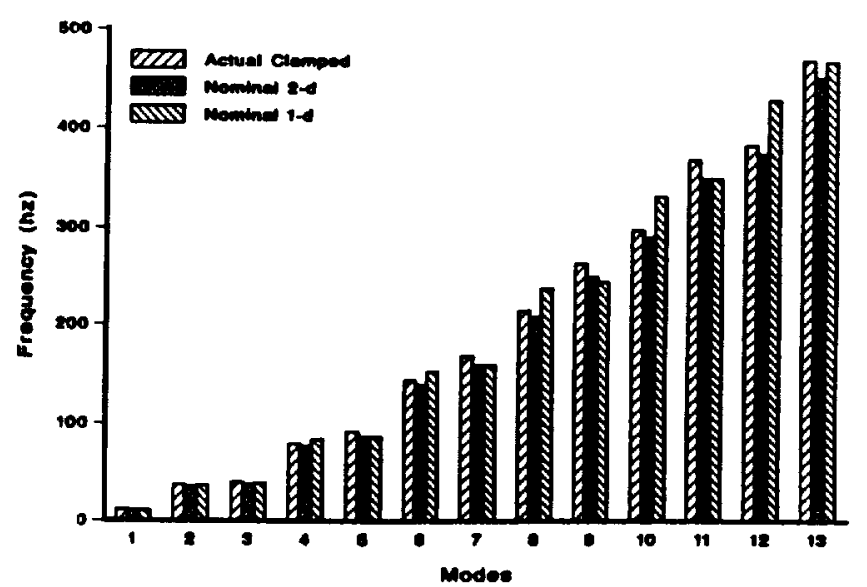

(a) Two-dimensional and one-dimensional beam model results.

Frequency, $\mathrm{Hz}$

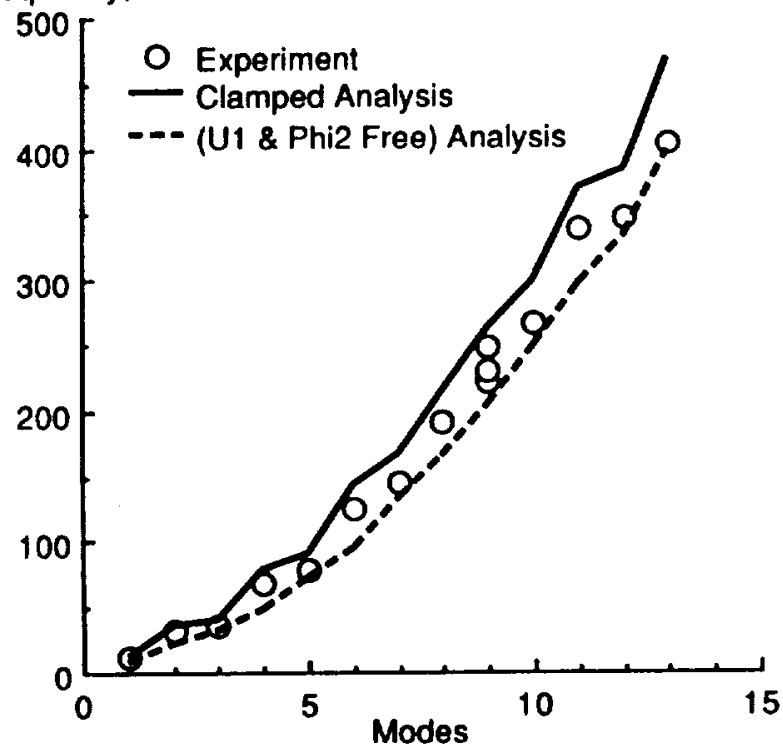

(b) Experimental and bounding two-dimensional model results.

Figure 10.- Comparison of finite element and experimental frequencies for the thin-walled composite frame with $\mathrm{J}$ cross-section. 


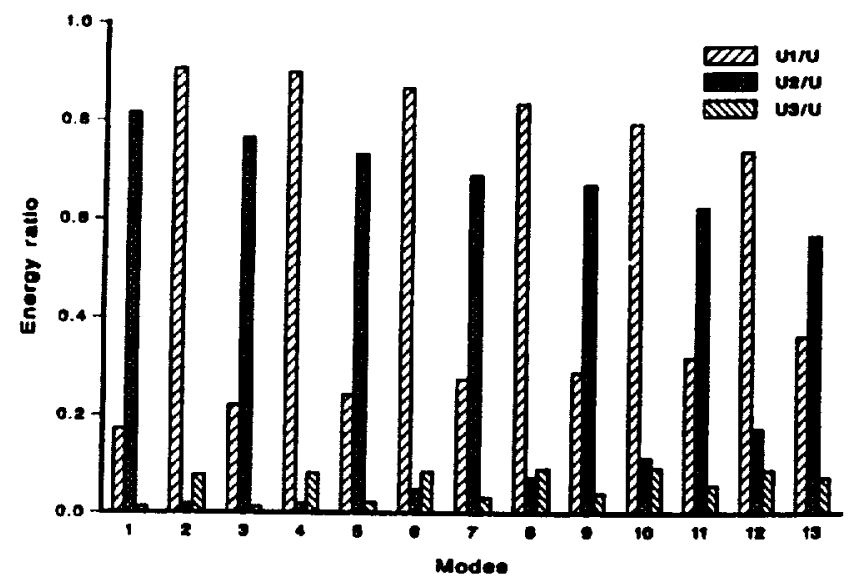

(a) $U_{1}, U_{2}$, and $U_{3}$ comoponents.

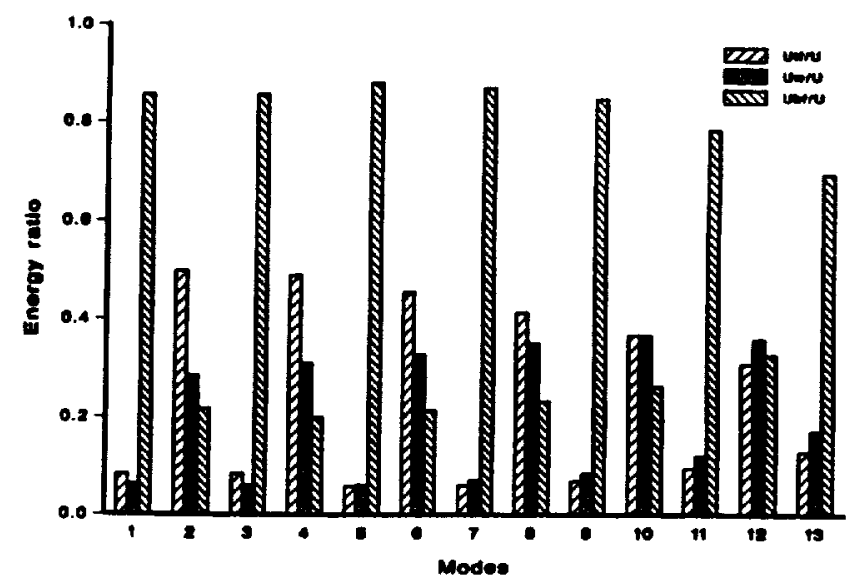

(b) $U_{t f}, U_{w}$, and $U_{b f}$ components.

Figure 11.- Energy components in the different vibration modes of the thin-walled composite frame with $\mathrm{J}$ cross-section.

Top View
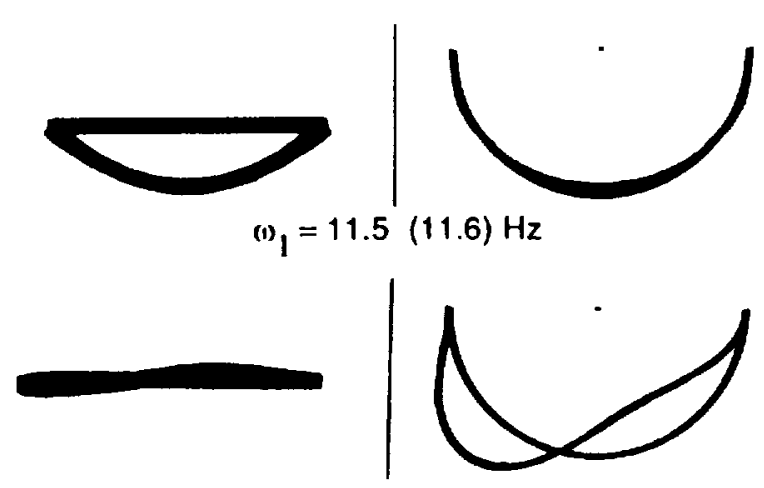

$(1)=11.5$

(11.6) $\mathrm{Hz}$

$(1)_{2}=36.9(32.1) \mathrm{Hz}$

Side View

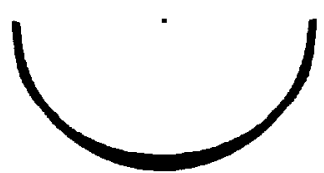

$(1)_{3}=39.8(37.0) \mathrm{Hz}$

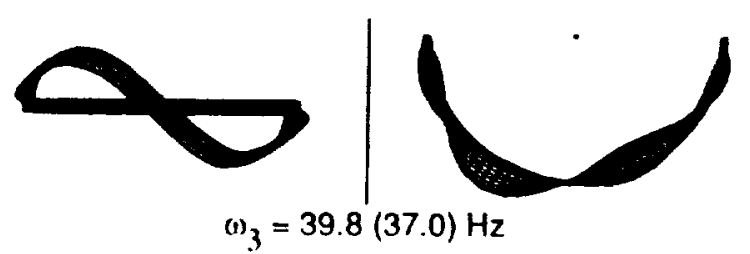

Nodal Lines on Top and Bottom Flanges
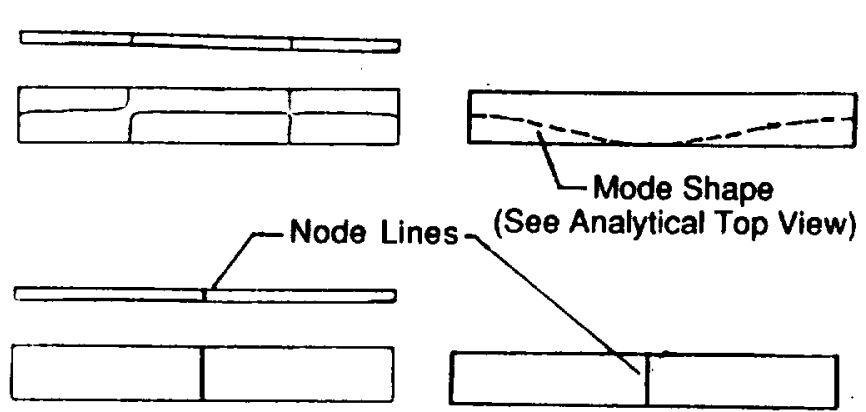

Experimental Node Lines (Bottom Flange)
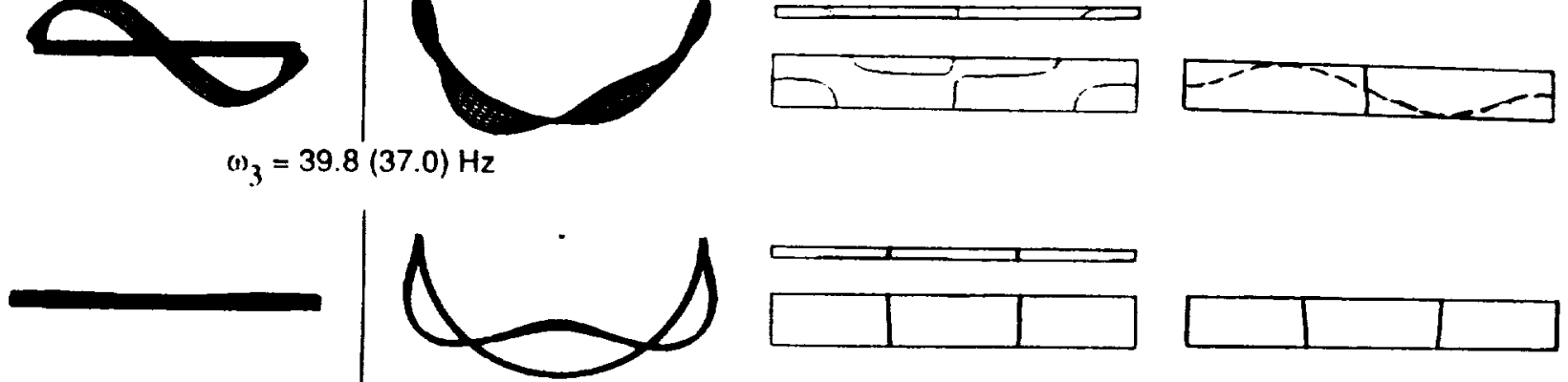

$(1)_{4}=79.2(69.0) \mathrm{Hz}$
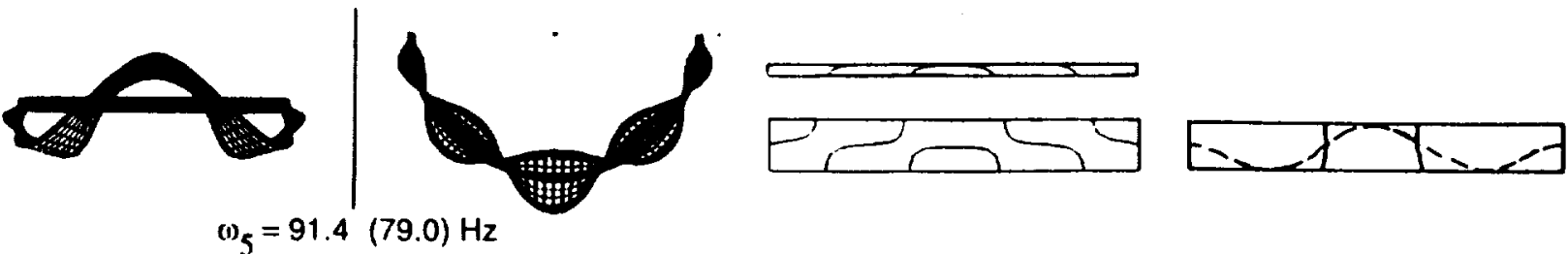

Figure 12.- Mode shapes associated with the five lowest frequencies of the thin-walled composite frame with $\mathrm{J}$ cross-section. Parentheses are experimental frequencies. Others are clamped finite element model results. 


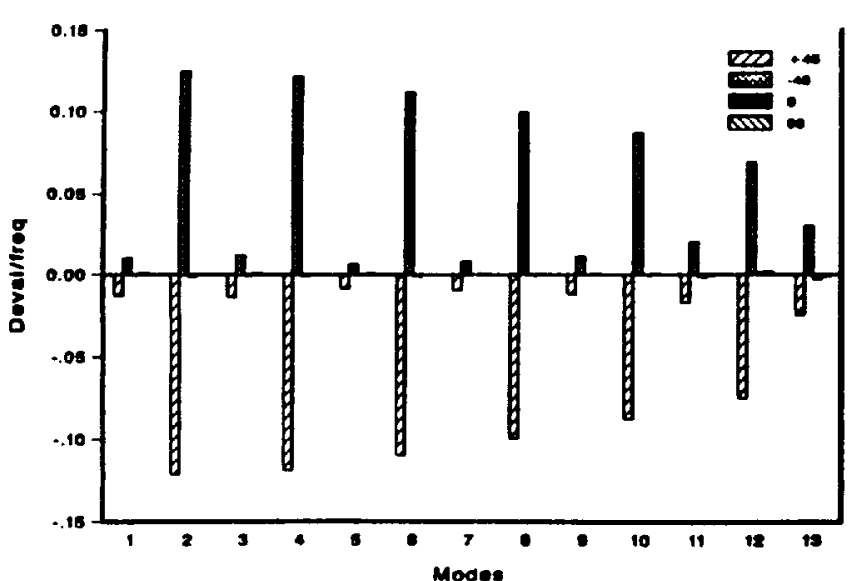

(a) Top flange.

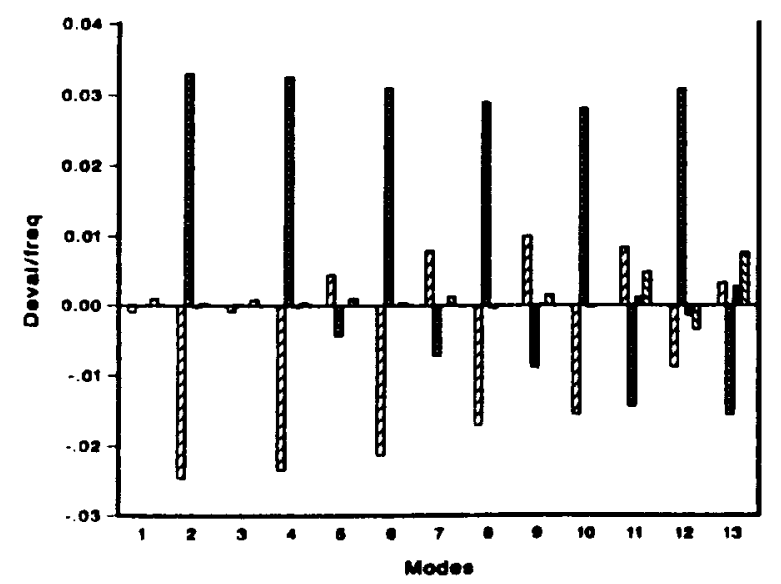

(b) Web.

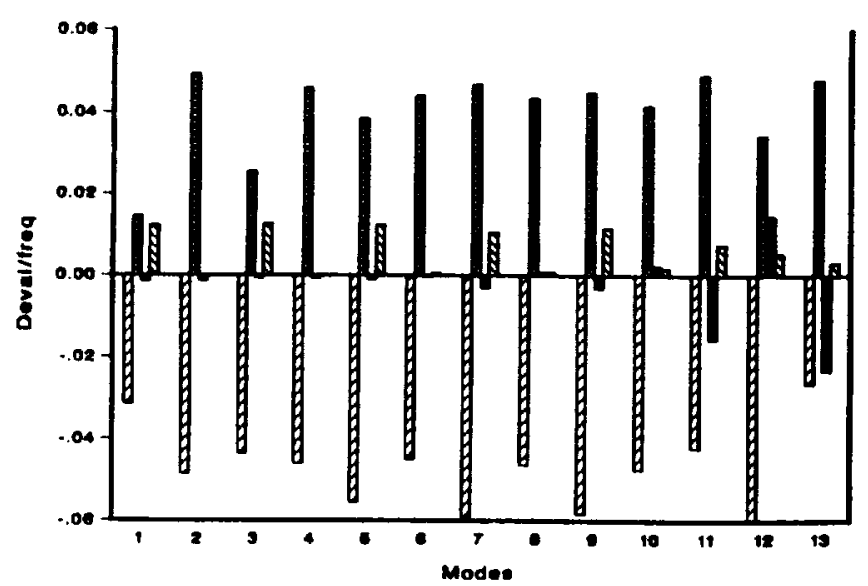

(c) Bottom flange and skin.

Figure 13.- Sensitivity of vibration frequencies to variations in the fiber orientation angle in the flanges and web of the thin-walled composite frame with $\mathrm{J}$ cross-section.

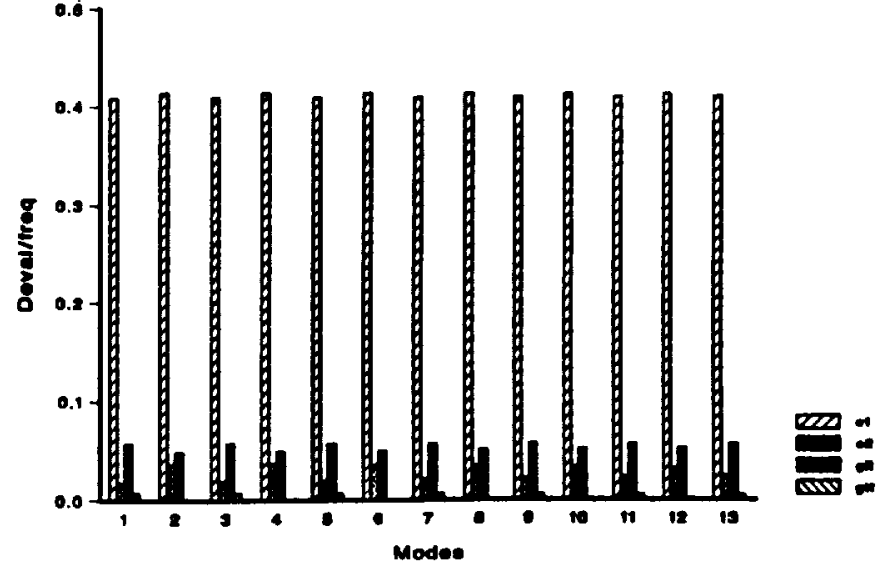

Figure 14.- Sensitivity of vibration frequencies to variations in the material characteristics of the thin-walled composite frame with $\mathrm{J}$ crosssection. 


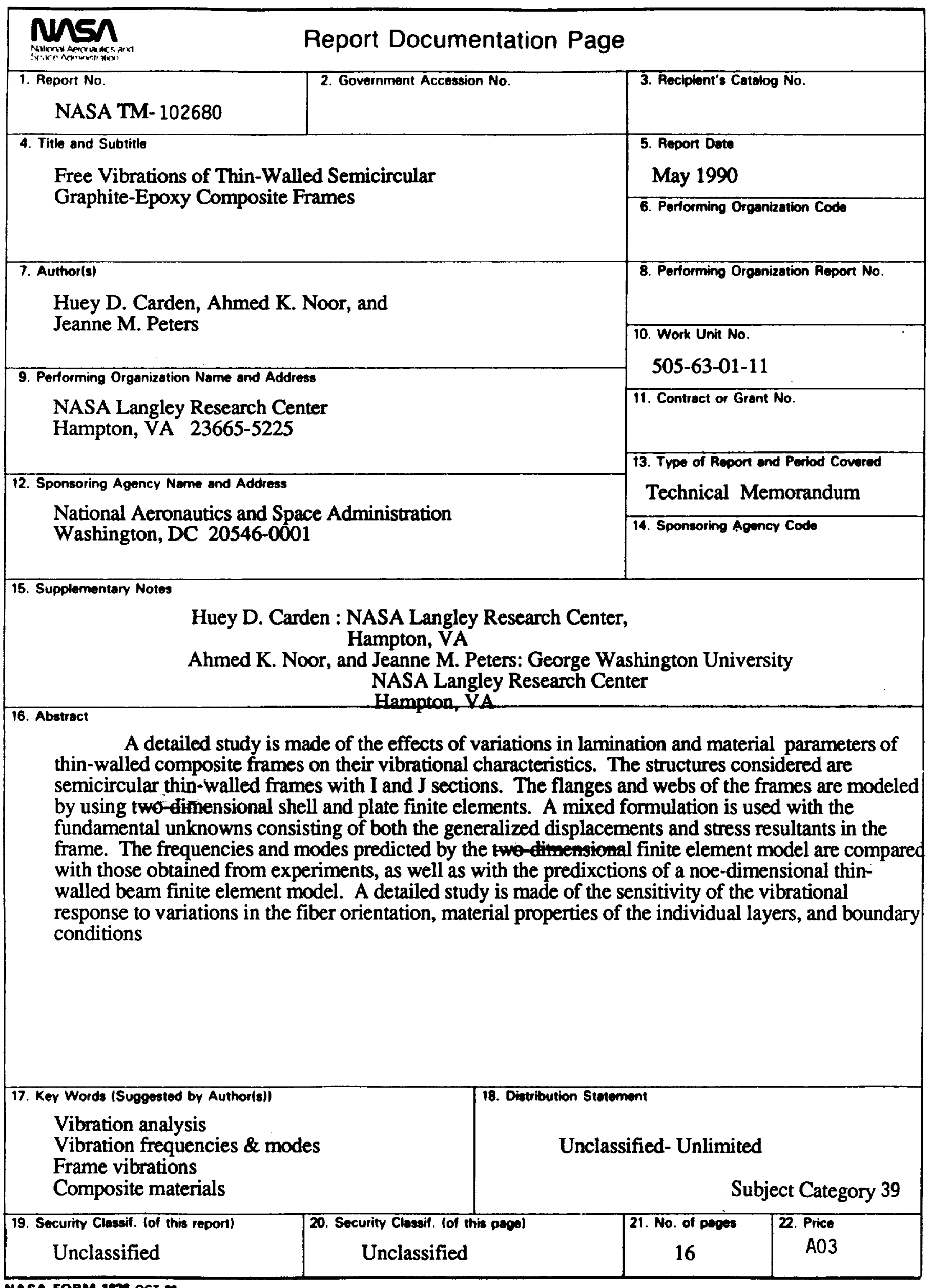

